\title{
Risk-Based Screening Analysis of Ground Water Contaminated by Radionuclides Introduced at the Nevada Test Site (NTS)
}

\author{
Jeffrey I. Daniels* \\ Roko Andricevic ${ }^{\dagger}$ \\ Lynn R. Anspaugh* \\ Roger L. Jacobson ${ }^{\dagger}$
}

June 1993

* Lawrence Livermore National Laboratory

University of California P.0. Box 808

Livermore, CA $94551-9900$

† Desert Research Institute

Water Resources Center

University and Community College System of Nevada

P.O. Box 19040

Las Vegas, NV 89132-0040 


\section{Acknowledgment}

We extend our appreciation and gratitude to the Nuclear Chemistry Division at the Lawrence Livermore National Laboratory (LLNL) and particularly to Dr. Wataru Goishi, Dr. Greg Nimz, Dr. Doug Leich, and Mr. Ken Marsh for providing essential data and insight regarding the presence of radionuclides in ground water beneath the NTS. We also thank Dr. Andrew Tompson in the Earth Sciences Division of the Geoscience and Environmental Research Program at the LLNL for reviewing the travel-time-transport model used in the assessment of the movement of radionuclides in ground water beneath the NTS. Additionally, we are grateful for the comments we received from the individuals we asked to examine the documents as external peer-reviewers and for the comments and cooperation provided by personnel at the U.S. Department of Energy (DOE), Nevada Operations Office in Las Vegas, NV; at U.S. DOE Headquarters in Washington, DC, and at U.S. DOE contracting organizations familiar with the NTS. 


\begin{abstract}
The Nevada Test Site (NTS) is located in the southwestern nart of Nevada, about $105 \mathrm{~km}$ $(65 \mathrm{mi})$ northwest of the city of Las Vegas. Underground tests of nuclear weapons devices have been conducted at the NTS since late 1962 and ground water beneath the NTS has been contaminated with radionuclides produced by these tests. No member of the public is expected to be exposed to this radionuclide-contaminated ground water in the immediate future. However, an increasing demand for water created by continued population growth and expanding development in the region and the possible loss of institutional control over the NTS after $100 \mathrm{y}$ have led to a concern that individuals in future generations might become exposed to the radionuclide-contaminated ground water. This concern prompted this examination of the potential health risk to these individuals from drinking the contaminated ground water either at a location on the NTS (assuming loss of institutional control after $100 \mathrm{y}$ ) or at one offsite (considering groundwater migration). For the purpose of this assessment, a representative mix of the radionuclides of importance and their concentrations in ground water beneath the NTS were identified from measurements of radionuclide concentrations in groundwater samples-ofopportunity collected at the NTS. Transport of radionuclide-contaminated ground water offsite was evaluated using a travel-time-transport approach. At both locations of interest, potential human-health risk was calculated for an individual ingesting radionuclide-contaminated ground water over the course of a 70-y lifetime. Uncertainties about human physiological attributes, as well as about estimates of physical detriment per unit of radioactive material, were quantified and incorporated into the estimates of risk. The maximum potential excess lifetime risk of sancer mortality estimated for an individual at the offsite location ranges from $7 \times 10^{-7}$ to $1 \times 10^{-5}$, and at the onsite location ranges from $3 \times 10^{-3}$ to $2 \times 10^{-2}$. Both the offsite and the onsite estimates of risk are dominated by the lifetime doses from tritium. For the assessment of radionuclides in ground water, the critical uncertainty is their concentration today under the entire NTS.
\end{abstract}

Key words: radionuclides, ground water, exposure, dose, risk analysis. 


\section{Contents}

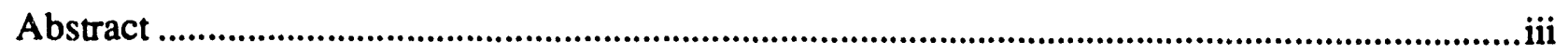

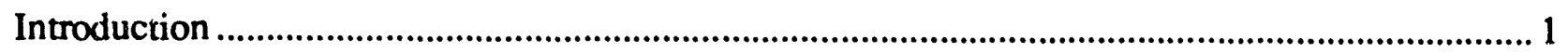

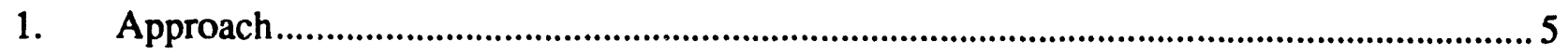

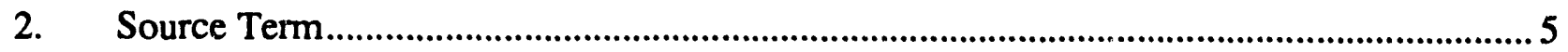

3. Estimation of Maximum Annual Concentrations of Radionuclides in Ground Water at Locations of Interest ......................................................................8

3.1. Radionuclide Concentrations at the Area 20 Boundary ...................................8

3.2. Radionuclide Concentrations at Oasis Valley .................................................8

4. Intake of Radionuclide-Contaminated Ground Water ................................................... 13

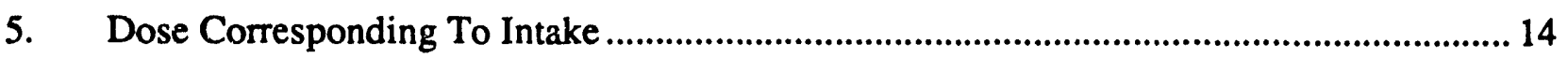

5.1. Dose-Conversion Factors for Intake by Ingestion ........................................ 15

5.2. Maximum Dose and Associated Uncertainty ................................................. 17

6. Estimate of Cancer Risk and Associated Uncertainty ................................................. 22

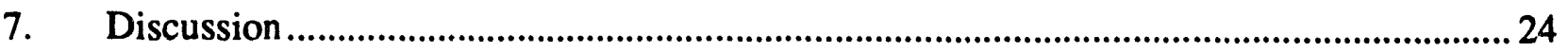

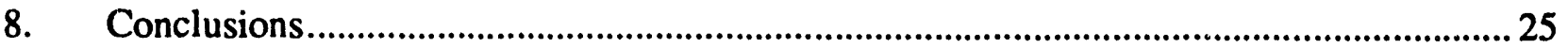

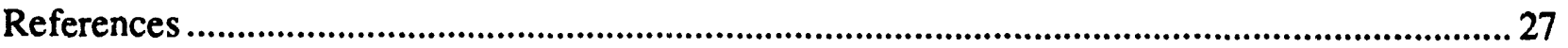




\section{Introduction}

The Nevada Test Site (NTS) is located in Nye County, Nevada, about $105 \mathrm{~km}$ (65 mi) northwest of the city of Las Vegas. Since 1951, the NTS has been used primarily for conducting tests of nuclear weapons devices; nearly all of the tests performed after late 1962 occurred underground in sealed vertical shafts or in horizontal tunnels (Wruble and McDowell, 1990). Figure 1 shows the location of the NTS in southern Nevada, the designated areas into which the NTS has been divided, and the buffer zone of restricted access formed by the Nellis Air Force Base Range Complex. Together, the NTS and the surrounding U.S. Air Force property occupy an area of about $14,200 \mathrm{~km}^{2}\left(5,470 \mathrm{mi}^{2}\right)$, which represents one of the largest unpopulated land areas in the U.S. today (Wruble and McDoweli, 1990).

Many of the underground tests of nuclear weapons devices at the NTS have been conducted at depths near or below the water table (Marsh, 1992). In Area 20, testing has occured below the water table near the boundary of the NTS. (The dot in Fig. 1 denotes approximately where testing occurred.) This boundary is also the closest site to existing groundwater wells offsite. These offsite wells are located to the southwest of the Area 20 boundary, beyond the buffer zone, in the Oasis Valley north of Beatty, NV. The wells are believed to be in the general direction of groundwater flow from Area 20.

Following underground detonation of nuclear weapons devices (also known as "shots") near or below the water table, a cavity is formed (see Fig. 2) and ground water that is displaced by explosive forces typically returns to fill the cavity. Although there have been only a very limited number of groundwater samples taken from or near shot cavities, the few samples-of-opportunity that have been collected reveal that many different radionuclides have been introduced into the returning ground water.

There are a number of reasons why the public is not considered in jeopardy of being exposed in the immediate future to the radionuclide-contaminated ground water beneath the NTS. First, access to the NTS (and its subterranean environment, including any radionuclide contaminated ground water), continues to be strictly controlled for security reasons. Second, slow groundwater movement and exceedingly slow downward movement of water in the overlying saturated zone at the NTS indicate that any radionuclides appearing in a deep groundwater aquifer are not likely to be transported rapidly to accessible locations offsite. Finally, there is no reported evidence to date to suggest that contaminated ground water from beneath the NTS has ever migrated offsite to an accessible area.

Recently, however, two issues have emerged that have led to a concern that future generations could become exposed to the radionuclide-contaminated ground water from the NTS. The southern part of Nevada and, specifically, the greater metropolitan area of Las Vegas, continue to experience a dramatic growth in population and development. This situation has created an ever increasing demand for a most limited resource in this arid region-water (Spencer, 1992). Purnping more ground water from beneath the agricultural lands nearest the NTS may be a way to provide some of the water needed to support this growth. Any radionuclide-contaminated ground water underneath the NTS that migrates to these offsite locations could then be pumped to the surface for purposes of consumption by humans. 


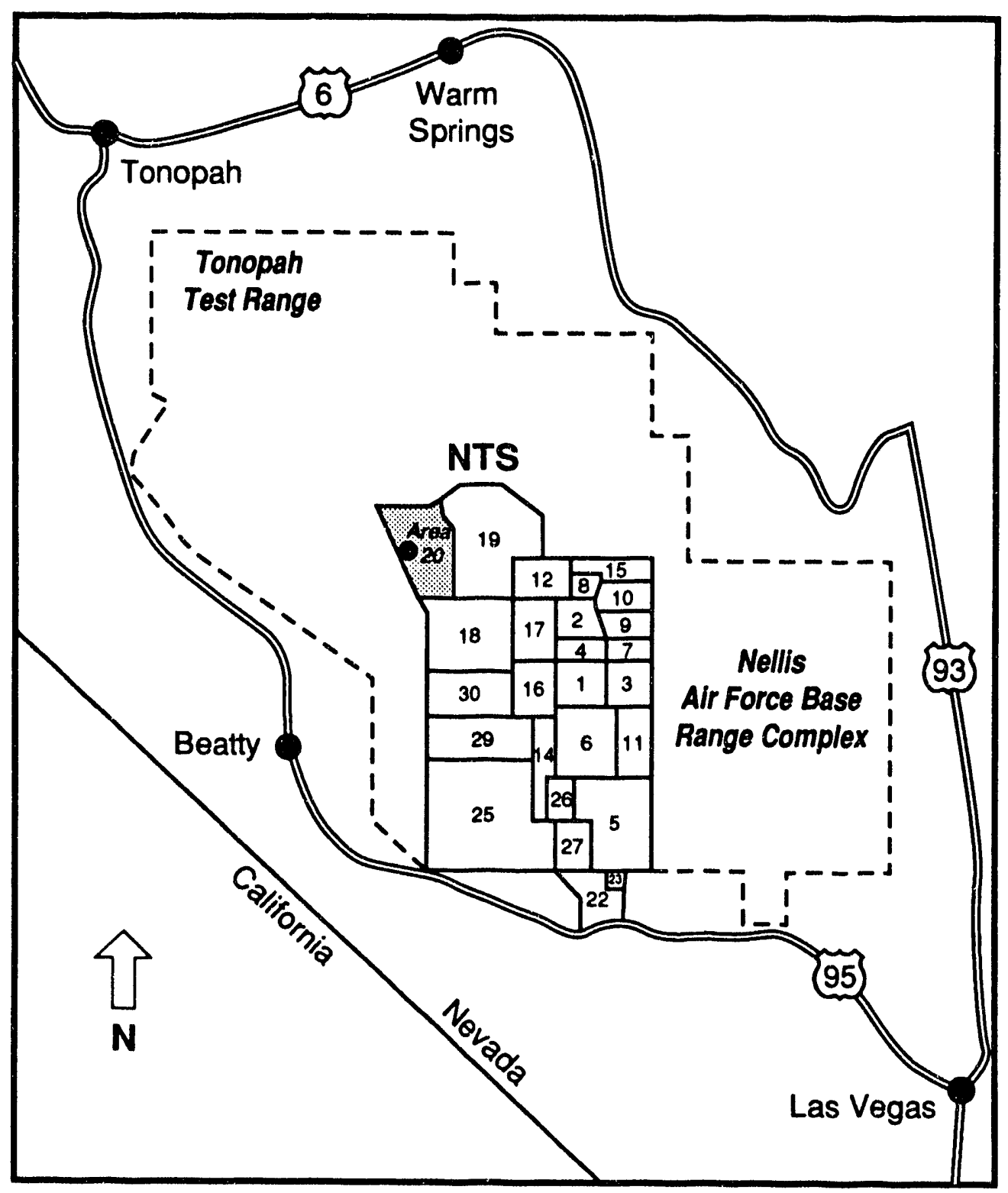

Figure 1. The Nevada Test Site (NTS) and vicinity in southern Nevada. Adapted from Wruble and McDowell (1990). 
Ground surface

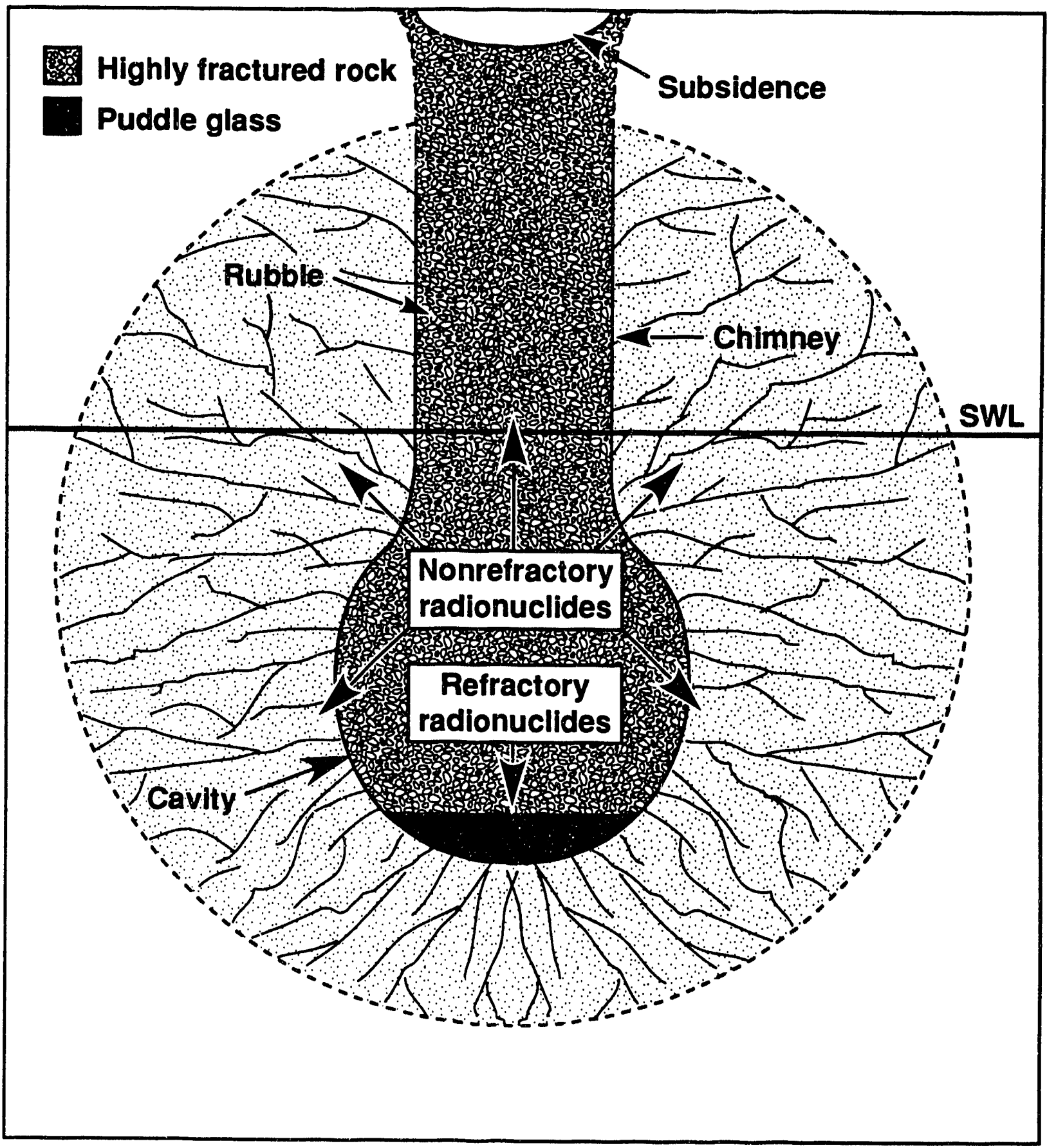

Figure 2. Cavity formation and other relevant geophysical features following detonation of a nuclear device below the standing water level (SWL) beneath the NTS. 
The other issue occurs because there is a temporary nuclear test moratorium in the U.S., which might become permanent before the end of the twentieth century; there is also a question of how long the U.S. Air Force range complex will exist in its present form and continue to provide a buffer zone around the NTS. Accordingly, the ultimate disposition and institutional control of the NTS and its buffer zone are now somewhat uncertain. A possible consequence of losing such institutional control is human intrusion onto or immediately next to the NTS. In this situation, the radionuclide-contaminated ground water from directly beneath the NTS could be pumped to the surface.

A sensible and effective strategy for addressing the concern raised by the issues just described is to estimate, as realistically and pragmatically as data permit, the magnitude and uncertainty of the potential public health risk associated with exposure to the radionuclidecontaminated ground water on the NTS and offsite in the direction of groundwater flow. The exposures associated with unacceptable levels of risk should then receive the most consideration with respect to devoting resources to their limitation or prevention, or further examination.

To accomplish this objective, a risk-based screening analysis was implemented to quantify the magnitude and uncertainty of the potential excess cancer mortality risk from the pertinent data available concerning this ground water at the NTS. Such pertinent data were so limited that it was necessary to adopt several conservative assumptions about radionuclide concentrations in the ground water, and about directions of groundwater flow, as well as about the exposure period (to include adults as well as infants and children).

Specifically, the risk-based screening analysis is designed to furnish conceivable ranges for the maximum potential incremental cancer mortality risk applicable to an exposed individual. Exposed individuals are considered to be those in future generations who might consume the ground water from the NTS over a 70-y lifetime either at a location on that border of the NTS (assuming loss of institutional control after $100 \mathrm{y}$ ) nearest the accessible offsite environment where ground water could be obtained, or at a location offsite in that nearby environment (considering groundwater migration).

The boundary of Area 20 was selected to represent the onsite location. It is the boundary of the NTS in closest proximity to existing groundwater wells offsite (in the Oasis Valley). A location $19 \mathrm{~km}$ away from the boundary of Area 20, in the Oasis Valley, was selected to represent the offsite location. This offsite location is considered to be in the general direction of groundwater flow from Area 20 and to be the nearest accessible offsite environment to the NTS for obtaining ground water.

The conceivable ranges for risk based on potential intakes of the NTS ground water at these onsite and offsite locations are more useful to decision makers than calculating maximum point estimates. For example, a conceivable range for risk reflects the combined uncertainty in the applicable input parameters. Additionally, a range for risk having significantly elevated upper and lower limits implies that a potentially serious threat to pubic health could be associated with intake of the NTS ground water at that particular location or perhaps at other locations in that category (e.g., onsite or offsite). 


\section{Approach}

$\therefore s$ mentioned previously, underground tests of nuclear weapons devices conducted at or belov the water table at the NTS have contaminated the ground water with a variety of different radionuclides. Unfortunately, the radionuclides themselves and their concentrations in this ground water have not been well characterized. For this reason a sequence of steps was developed to determine a conceivable range for the maximumi incremental cancer risk for an individual consuming the NTS ground water either onsite at the Area 20 boundary beginning after $100 \mathrm{y}$, or offsite, $19 \mathrm{~km}$ away in the Oasis Valley after possible migration of the ground water from the Area 20 boundary.

The first step in the approach involves identifying those radionuclides and their maximum concentrations that are representative of the mix that could be present in the ground water beneath the Area 20 boundary today. This collection of radionuclides and their maximum concentrations then serve as the source term for the next step, projecting maximum groundwater concentrations for these radionuclides at the specific onsite and offsite locations for each year during an entire 70-y lifetime. In the third step, the potential lifetime internal doses are determined for an individual at each location. The last step entails estimating the probability of developing a fatal cancer per unit dose, and then using that estimate to compute maximum potential excess lifetime-cancer-mortality risk for each of the potential lifetime internal doses. Because parameter uncertainties and correlations are assessed and propagated throughout the entire process, the calculated estimates of maximum potential excess lifetime-cancer-mortality risk are expressed as ranges of values that reflect the overall uncertainty.

\section{Source Term}

Published measurements of radionuclide concentrations in ground water sampled from shot cavities beneath the NTS were used to as - - + n in the representative mix of radionuclides and their maximum concentrations that could be present today in the ground water beneath the Area 20 boundary. Included among these radionuclides are those with short or long half lives and those that are radiologically important in terms of producing adverse health effects following intake.

Unfortunately, relevant groundwater sampling data were available from only three shot cavities created at different locations beneath the NTS. However, each of these three shot cavities was at or below the water table and the groundwater samples were taken either by penetration of the shot cavity or the geologic material immediately near it. Figure 3 shows the designated areas of the NTS; some major natural topographic features, including the Oasis Valley; and the locations of the three shot cavities (Cheshire in Area 20, Bilby in Area 3, and Cambric in Area 5) from which the groundwater samples-of-opportunity were obtained. For purposes of this assessment, the basis for reasonable first approximations for the representative mix and corresponding maximum concentrations of radionuclides that could be present today in ground water beneath the Area 20 boundary are the radionuclides and their associated maximum concentrations measured at the time of collection in the groundwater samples-of-opportunity obtained from the three shot cavities. This representative mix of radionuclides, along with their maximum observed concentrations $\left(\mathrm{Bq} \mathrm{L}^{-1}\right)$ and original sampling locations, are presented in Table 1. 
Table 1. Maximum observed concentrations $\left(\mathrm{Bq} \mathrm{L}^{-1}\right)$ of radionuclides measured at the time of collection in groundwater samples-of-opportunity from three different shot cavities under the Nevada Test Site, representative of the mix at Area 20.

\begin{tabular}{|c|c|c|c|}
\hline Radionuclide & $\begin{array}{l}\text { Maximum observed } \\
\text { concentration } \\
\left(\mathrm{Bq} \mathrm{L}^{-\mathbf{1}}\right)^{\mathbf{a}}\end{array}$ & $\begin{array}{l}\text { NTS sampling } \\
\text { location (shot cavity) }\end{array}$ & Reference \\
\hline Americium-241 & $9.2 \times 10^{-2}$ & Area 20 (Cheshire) & Buddemeier and Isherwood (1985) \\
\hline Antimony-125 & $4.4 \times 10^{+2}$ & Area 5 (Cambric) & Hoffman et al. (1977) \\
\hline Cerium-144 & $8.1 \times 10^{-1}$ & Area 20 (Cheshire) & Buddemeier and Isherwood (1985) \\
\hline Cesium-137 & $1.8 \times 10^{+2}$ & Area 5 (Cambric) & Hoffman et al. (1977) \\
\hline Cobalt- 60 & $1.2 \times 10^{-1}$ & Area 20 (Cheshire) & Buddemeier (1988) \\
\hline Europium-152 & $4.1 \times 10^{-1}$ & Area 20 (Cheshire) & Buddemeier and Isherwood (1985) \\
\hline Iodine-129 & $4.1 \times 10^{-1}$ & Area 5 (Cambric) & Fraser (1982) \\
\hline Plutonium-239 & $2.3 \times 10^{-1}$ & Area 5 (Cambric) & Hoffman et al. (1977) \\
\hline Radium-226 & $1.1 \times 10^{-1}$ & Area 3 (Bilby) & Erikson and Jacobson (1990)b \\
\hline Ruthenium-106 & $3.3 \times 10^{-1}$ & Area 5 (Cambric) & Hoffman et al. (1977) \\
\hline Strontium-90 & $1.5 \times 10^{+2}$ & Areä 5 (Cambric) & Hoffman et al. (1977) \\
\hline Technetium-99 & $2.6 \times 10^{+0}$ & Area 3 (Bilby) & Silva et al. (1986) \\
\hline Tritium [H-3] & $2.8 \times 10^{+8}$ & Area 5 (Cambric) & Hoffman et al. (1977) \\
\hline Uranium-234 & $1.8 \times 10^{-1}$ & Area 3 (Bilby) & Erikson and Jacobson (1990)C \\
\hline Uranium-235 & $3.2 \times 10^{-2}$ & Area 3 (Bilby) & Buddemeier and Isherwood (1985) \\
\hline Uranium-238 & $1.0 \times 10^{+0}$ & Area 3 (Bilby) & Buddemeier and Isherwood (1985) \\
\hline \multicolumn{4}{|c|}{ Rounded values; to convert $B q \mathrm{~L}^{-1}$ to $\mathrm{pC}$. $\mathrm{mL}^{-1}$ multiply $\mathrm{Bq} \mathrm{L}^{-1}$ by $2.7 \times 1 \sigma^{-2}$. } \\
\hline \multicolumn{4}{|c|}{$\begin{array}{l}\text { U.S. Environmental Protection Agency (EPA) raw data collected in } 1974 \text { as part of the } 1974 \text { U.S. EPA Long-Term } \\
\text { Hydrologic Monitoring Program (LTHM). }\end{array}$} \\
\hline \multicolumn{4}{|c|}{$\begin{array}{l}\text { U.S. Environmental Protection Agency (EPA) raw data collected in } 1973 \text { as part of the } 1973 \text { U.S. EPA Long-Term } \\
\text { Hydrologic Monitoring Program (LTHM). }\end{array}$} \\
\hline
\end{tabular}

As indicated in Figure 3, the approximate distance from the southwestern boundary of Area 20 to that part of the Oasis Valley just outside the buffer zone is $19 \mathrm{~km}(12 \mathrm{mi})$. Ground water flows in volcanic rocks beneath Area 20 in the general direction of the Oasis Valley. The water table below Area 20 typically is found at depths from about 580 to $730 \mathrm{~m}(1,900$ to $2,400 \mathrm{ft}$ ) and contains water ranging in age from 10,000 to 15,000 years before present time. It is hypothesized that the most dramatic movement within this system would probably occur along highly transmissive fractures, many of which could be present beneath the NTS. The characteristics of this aquifer system are described in detail by Winograd and Thordarson (1975). 


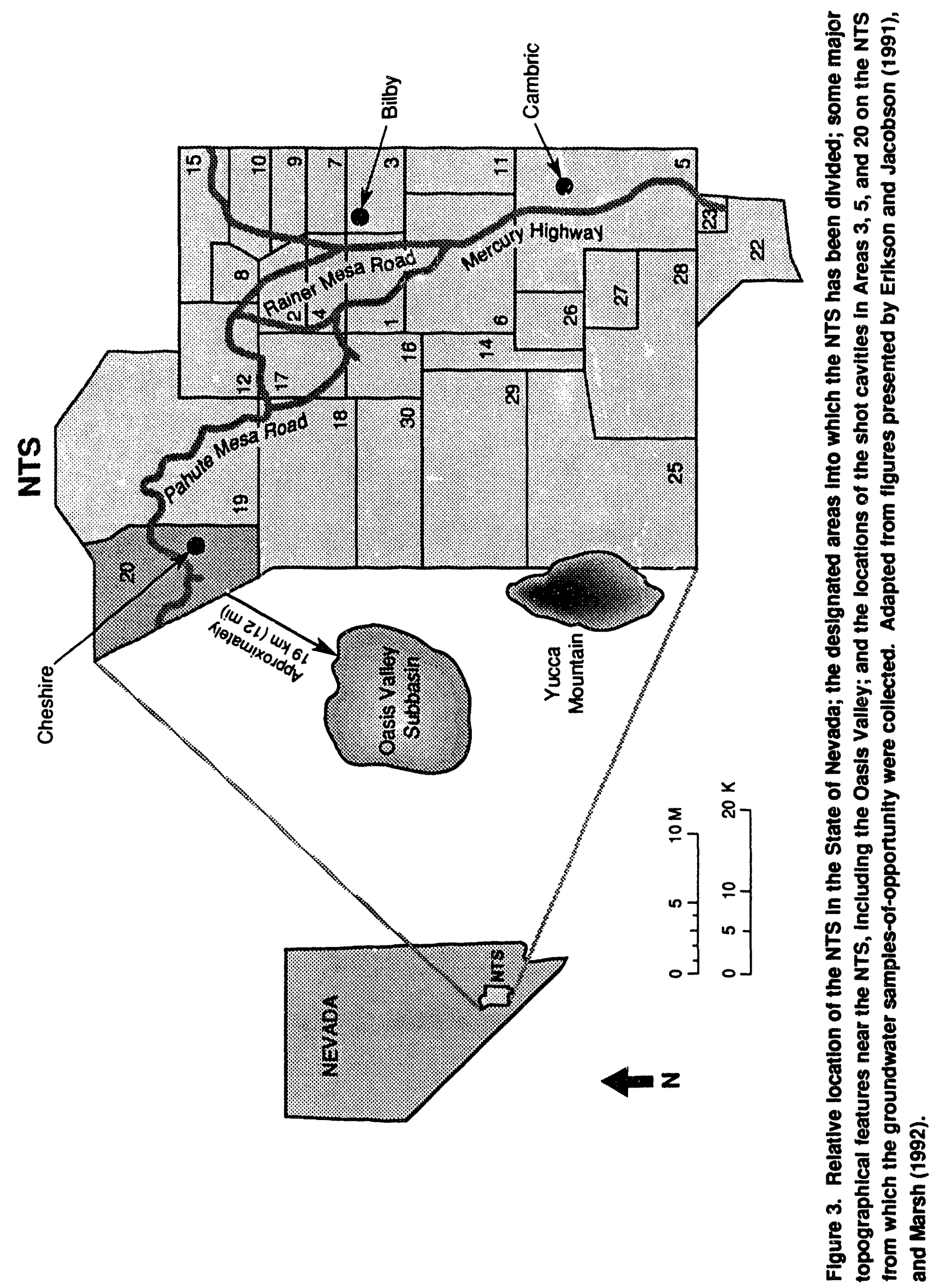




\section{Estimation of Maximum Annual Concentrations of Radionuclides in Ground Water at Locations of Interest}

Water consumption $t y$ an individual at the boundary of Area 20 is assumed to begin $101 \mathrm{y}$ in the future. Water consumption $19 \mathrm{~km}$ away from the Area 20 boundary in the Oasis Valley is considered to commence at the beginning of a hypothetical 70-y interval when all of the radionuclides in the ground water from the Area 20 boundary are predicted to have arrived at the Oasis Valley and to be present at their respective maximum annual concentrations. At both locations of potential exposure, an individual is considered to consume the ground water for an entire 70-y lifetime.

Because data describing the movement of radionuclides in ground water at the NTS is so limited, the concentrations of the radionuclides in the ground water are considered to be affected only by radioactive decay. Therefore, no account is taken of possible removals through sorption of radionuclides on geologic material along the groundwater-flow path, nor are the radionuclide concentrations assumed to be diluted by the inflow of noncontaminated ground water. On the basis of these conservatisms, the projected annual concentrations for the representative mix of radionuclides at both locations are regarded as estimates of maximum values.

\subsection{Radionuclide Concentrations at the Area 20 Boundary}

As a consequence of these assumptions, the maximum annual concentrations of radionuclides in the ground water at the Area 20 boundary can be calculated for each year of a 70-y interval beginning $101 \mathrm{y}$ in the future using the first-order decay equation:

$$
A(t)=A(0) e^{-\lambda t}
$$

In Equation 1, $A(t)$ is the concentration $\left(\mathrm{Bq} \mathrm{L}^{-1}\right)$ at time $\mathrm{t}(\mathrm{y})$ in the future at the Area 20 boundary, $A(0)$ is the maximum concentration assumed to be present today at the Area 20 boundary (Bq L $~^{-1}$ appearing in Table 1 ), and $\lambda$ is the radioactive decay constant [0.693/half life (y) for the radionuclide of interest]. Table 2 shows the ranges for the predicted annual concentrations of the radionuclides in the ground water at the Area 20 boundary during the $70-y$ interval beginning $101 \mathrm{y}$ hence.

\subsection{Radionuclide Concentrations at Oasis Valley}

The second location for estimating radionuclide intake is at the edge of the Oasis Valley, $19 \mathrm{~km}(12 \mathrm{mi})$ southwest of the Area 20 boundary (see Fig. 3). To determine the potential maximum annual radionuclide concentrations in the ground water over a $70-y$ interval in the future, allowance must be made for the radioactive decay of the radionuclides during the time of their migration in the ground water from the Area 20 boundary. Again, it is assumed that the initial concentrations of the representative mix of radionuclides at the Area 20 boundary today 
Table 2. Predicted ranges for the maximum annual concentrations $\left(B \mathrm{q} \mathrm{L}^{-1}\right)$ in ground water of the representative mix of radionuclides during a 70-y interval in the future at the Area 20 boundary (after decay), and $19 \mathrm{~km}$ away, offsite in the Oasis Valley (after migration).

\begin{tabular}{|c|c|c|c|c|c|c|c|}
\hline \multirow{3}{*}{$\begin{array}{c}\text { Radionuclide } \\
\text { Americium-241 }\end{array}$} & \multicolumn{7}{|c|}{$\begin{array}{l}\text { Range for maximum annual } \\
\text { concentrations }\left(\mathrm{Bg} L^{-1}\right)^{b} \text { over } 70-y \text { period }\end{array}$} \\
\hline & \multicolumn{3}{|c|}{$\begin{array}{l}\text { Area } 20 \text { boundary } \\
\text { (101 to } 170 \text { y due to decay) }\end{array}$} & \multicolumn{3}{|c|}{$\begin{array}{l}\text { Oasis Valley } \\
\text { offsite }\end{array}$} & \multirow{2}{*}{$\frac{\begin{array}{c}\text { (70-y interval } \\
\text { due to travel) }\end{array}}{\text { (344 to } 413)}$} \\
\hline & $7.8 \times 10^{-2}$ & to & $7.0 \times 10^{-2}$ & $2.6 \times 10^{-5}$ & to & $2.7 \times 10^{-5}$ & \\
\hline Antimony-125 & $7.8 \times 10^{-9}$ & to & $3.0 \times 10^{-16}$ & $2.3 \times 10^{-27}$ & to & $3.6 \times 10^{-7}$ & (1 to 70$)$ \\
\hline Cerium-144 & $20 \times 10^{-38}$ & to & $2.1 \times 10^{-64}$ & $8.9 \times 10^{-32}$ & to & $8.1 \times 10^{-13}$ & $(1$ to 70$)$ \\
\hline Cesium-137 & $1.8 \times 10^{+1}$ & to & $3.7 \times 10^{+0}$ & $8.9 \times 10^{-4}$ & to & $1.2 \times 10^{-3}$ & (72 to 141) \\
\hline Cobalt -60 & $2.6 \times 10^{-7}$ & to & $3.1 \times 10^{-11}$ & $5.6 \times 10^{-24}$ & to & $2.6 \times 10^{-9}$ & (1 to 70$)$ \\
\hline Europium-152 & $2.2 \times 10^{-3}$ & to & $5.9 \times 10^{-5}$ & $7.4 \times 10^{-8}$ & to & $2.6 \times 10^{-7}$ & (28 to 97$)$ \\
\hline Iodine-129 & $4.1 \times 10^{-1}$ & to & $4.1 \times 10^{-1}$ & $2.4 \times 10^{-4}$ & to & $2.4 \times 10^{-4}$ & (539 to 608$)$ \\
\hline Plutonium-239 & $2.3 \times 10^{-1}$ & to & $2.3 \times 10^{-1}$ & $1.4 \times 10^{-4}$ & to & $1.4 \times 10^{-4}$ & (533 to 602 ) \\
\hline Radium-226 & $1.1 \times 10^{-1}$ & to & $1.0 \times 10^{-1}$ & $5.2 \times 10^{-5}$ & to & $5.2 \times 10^{-5}$ & (461 to 530$)$ \\
\hline Ruthenium-106 & $2.6 \times 10^{-28}$ & to & $4.4 \times 10^{-49}$ & $6.7 \times 10^{-24}$ & to & $1.3 \times 10^{-9}$ & $(1$ to 70$)$ \\
\hline Strontium-90 & $1.4 \times 10^{+1}$ & to & $2.7 \times 10^{+0}$ & $6.7 \times 10^{-4}$ & to & $8.9 \times 10^{-4}$ & (70 to 139) \\
\hline Technetium-99 & $26 \times 10^{+0}$ & to & $2.6 \times 10^{+0}$ & $1.6 \times 10^{-3}$ & to & $1.6 \times 10^{-3}$ & (539 to 608) \\
\hline Tritium [H-3] & $1.1 \times 10^{+6}$ & to & $2.3 \times 10^{+4}$ & $3.3 \times 10^{+1}$ & to & $1.4 \times 10^{+2}$ & (25 to 94) \\
\hline Uranium-234 & $1.9 \times 10^{-1}$ & to & $1.9 \times 10^{-1}$ & $1.1 \times 10^{-4}$ & to & $1.1 \times 10^{-4}$ & (539 to 608$)$ \\
\hline Uranium-235 & $2.6 \times 10^{-2}$ & to & $2.6 \times 10^{-2}$ & $1.9 \times 10^{-7}$ & to & $1.9 \times 10^{-7}$ & (539 to 608$)$ \\
\hline Uranium-238 & $1.0 \times 10^{+0}$ & to & $1.0 \times 10^{+0}$ & $5.9 \times 10^{-4}$ & to & $5.9 \times 10^{-4}$ & (539 to 608) \\
\hline \multicolumn{8}{|c|}{$\begin{array}{l}\text { Based on maximum concentrations reported for these radionuclides at the time of the collection of } \\
\text { groundwater samples-of-opportunity from three shot cavities on NTS (see Table } 1 \text { and Fig. } 3 \text { ). }\end{array}$} \\
\hline \multicolumn{8}{|c|}{ b Rounded values; to convert Bq L $\mathrm{L}^{-1}$ to $\mathrm{pCi} \mathrm{mL}^{-1}$ multiply Bq L-1 by $2.7 \times 10^{-2}$. } \\
\hline \multicolumn{8}{|c|}{$\begin{array}{l}\text { The } 70-y \text { period during which the maximum annual concentrations for a radionuclide are predicted to be } \\
\text { present at the Oasis Valley, based on the results of the travel-time transport model. }\end{array}$} \\
\hline
\end{tabular}

equate to the maximum concentrations of these radionuclides measured at the time of collection in the samples-of-opportunity from the Cambric, Cheshire, and Bilby shot cavities.

Precise hydrogeological data concerning groundwater migration from the NTS to offsite locations, such as the Oasis Valley, are not available. Therefore, a classical hydrological transport model that would employ such information and accurately predict a point estimate of activity of a radionuclide at a particular location spatially and temporally cannot be employed. Instead, the travel-time-transport approach, which is not dependent on such detailed information, will be used. The principal output of the model is a probability-density function (pdf) conditioned on the set of parameters used to describe processes such as velocity, advection, dispersion, and radioactive decay. Importantly, the travel-time-transport model takes into consideration parameter uncertainty and any possible correlation among parameters. 
Flux-averaged concentrations, which are defined in terms of the ratio of solute flux to water flux (Kreft and Zuber, 1978), are used as input parameters. Therefore, the maximum concentrations for the representative mix of radionuclides assumed to be present in ground water beneath the Area 20 boundary today (see Table 1) are considered to represent flux-averaged concentrations and are input directly into the model.

The travel-time distribution is derived from the Lagrangian concept of particle displacement (Taylor, 1921; Dagan, 1982, 1984, 1987; Shapiro and Cvetkovic, 1988; Dagan and Nguyen, 1989). In this concept, the solute is represented as a collection of particles transported by ground water under advection, dispersion, and other physical and chemical processes. The groundwaterflow velocity ( $\mathrm{Vx}, \mathrm{Vy}$, and $\mathrm{Vz}$ ) satisfies Darcy's law and the equation of continuity and will fluctuate from one point $(x, y, z)$ to another because of locally variable hydrogeologic conditions. We assume that the velocity distribution can be decomposed into (i.e., represented as) a mean, or average value of magnitude $U$ aligned with the $x$ axis, and a fluctuating part whose spatial average is zero. The travel time for a solute particle to move a distance $L$ in the mean-flow ( $x$ ) direction may be estimated from (Shapiro and Cvetkovic, 1988)

$$
t(L)=\int_{0}^{L} \frac{d x}{V x}
$$

where $V x=V x(x, 0,0)$ is the $x$-component of the velocity along the $x$ axis. For our purpuses, the $x$ axis will be anchored at the boundary of Area 20 and point toward the Oasis Valley. Radionuclide transport and travel-time analyses will be considered along this path using $\mathrm{L}=19 \mathrm{~km}$. On the basis of the limited data available for NTS hydrogeology, the velocity component, $\mathrm{Vx}$, of the ground water migrating in the direction of the Oasis Valley is cronsidered to be a lognormally distributed variable with an expected value (arithmetic mean). U, equal to $17 \mathrm{~m} / \mathrm{y}$ (derived from data presented by Blankennagel and Weir, 1973; and Winograd and Thordarson, 1975). As a consequence of the uncertainties in the transport mechanism, such as estimation of parameters characterizing flow and transport, and spatial variability of the aquifer properties, such as permeability and porosity, radionuclide arrival at Oasis Valiey in ground water migrating from the Area 20 boundary will be distributed in time and described by a lognormal travel-time pdf, $\mathrm{p}[\mathrm{t} ; \mathrm{L} \mid \mathrm{U}]$ (Andricevic et al., 1993). Different velocities associated with locally variable hydrogeologic conditions will tend to transport different elements of an initial pulse of mass at different rates; hence, downstream arrival times will be distributed according to $\mathrm{p}[\mathrm{t} ; \mathrm{L} \mid \mathrm{U}]$. The product of $\mathrm{p}[\mathrm{t} ; \mathrm{L} \mid \mathrm{U}]$ and a time interval, $\mathrm{dt}$, represents the fraction of mass released at $x=0, t=0$ that arrives at $x=L$ between $t$ and $t+d t$, conditioned on a mean velocity, $U$ (as we see later, the estimate of this average may, in fact, be uncertain, and may be associated with its own lognormal pdf, $\mathrm{p}[\mathrm{U}])$. The incorporation of radioactive decay in the travel-time-transport model will result in a modified travel-time pdf, $\tilde{p}[t ; L \mid U]$, because longer travel times will become less likely as a result of decay along travel paths:

$$
\tilde{p}[t ; L \mid U]=\exp \left(-\frac{\ln 2}{\frac{t}{2}} t\right) p[t ; L \mid U]
$$


Here, $t$ is the travel time $(y), t_{\frac{1}{2}}$ is the radioactive half-life $(y)$ of the radionuclide of interest, and $\mathrm{p}[\mathrm{t} ; \mathrm{L} \mid \mathrm{U}]$ is the travel-time pdf of the solute conditioned on the uncertainty coming from the estimated mean velocity, $U$, and which takes the form of the lognormal distribution. The modified travel-time pdf has to be rormalized to obtain the full travel-time pdf; this is accomplished by dividing the right side of that equation by the constant $\mathrm{C}$, which is obtained from the following expression:

$$
C=\int_{0}^{\infty} \exp \left(-\frac{\ln 2}{t_{\frac{1}{2}}} t\right)[t ; L / U] d t
$$

Thus, the unconditional travel-time cumulative distribution function (cdf), $G\left[t^{*} ; L\right]$, can be expressed mathematically as

$$
G\left[t^{*}: L j=\int_{0}^{t^{*}} \int_{0}^{\infty} \exp \left(-\frac{\ln 2}{t_{\frac{1}{2}}} t\right) p[t ; L / U] p[U] d t d U,\right.
$$

where $t^{*}$ is the travel time of interest $(y), t_{\frac{1}{2}}$ is the radioactive half-life of the radionuclide of interest; and $p[t ; L \mid U]$ is the travel-time pdf of the solute. This last parameter is lognormal, conditioned on the uncertainty coming from the estimated mean velocity, $U$, and accounts for advection and hydrodynamic dispersion. The term, $\mathrm{p}[\mathrm{U}]$, is the pdf of the mean velocity estimate, which also takes the form of the lognormal distribution. The integration of the cdf equation is performed numerically. The cdf expression is used to estimate the accumulation over time of each radionuclide at Oasis Valley following transport in ground water from the Area 20 boundary. This information is then employed to determine the 70 maximum annual concentrations of each radionuclide in the ground water at Oasis Valley and the corresponding 70-y interval during which these concentrations occur. ${ }^{*}$ The range of maximum annual concentrations for each radionuclide of interest in groundwater at Oasis Valley is shown in Table 2, along with the 70-y interval associated with these concentrations.

The maximum annual concentrations appearing in Table 2 are assumed to be geometric mean values of lognormally distributed variables, and the geometric standard deviation corresponding to each of the values for Oasis Valley is assumed to equal 2.0. By not incorporating into the travel-time-transport calculations the possibility of sorption of radionuclides on geologic material along the flow path, the remote possibility is addressed that radionuclides sorbed to geologic material could still be transported in ground water as a result of the movement of the geologic material as a colloid from the Area 20 boundary to the Oasis Valley.

Figure 4 graphically illustrates the impact of radioactive decay on the travel-time pdf for radionuclides arriving at Oasis Valley in ground water migrating from the Area 20 boundary. As

\footnotetext{
The concentration of a radionuclide in any single year can be derived from the model. The $70-y$ interval containing the maximum annual concentrations are then selected for this assessment.
} 


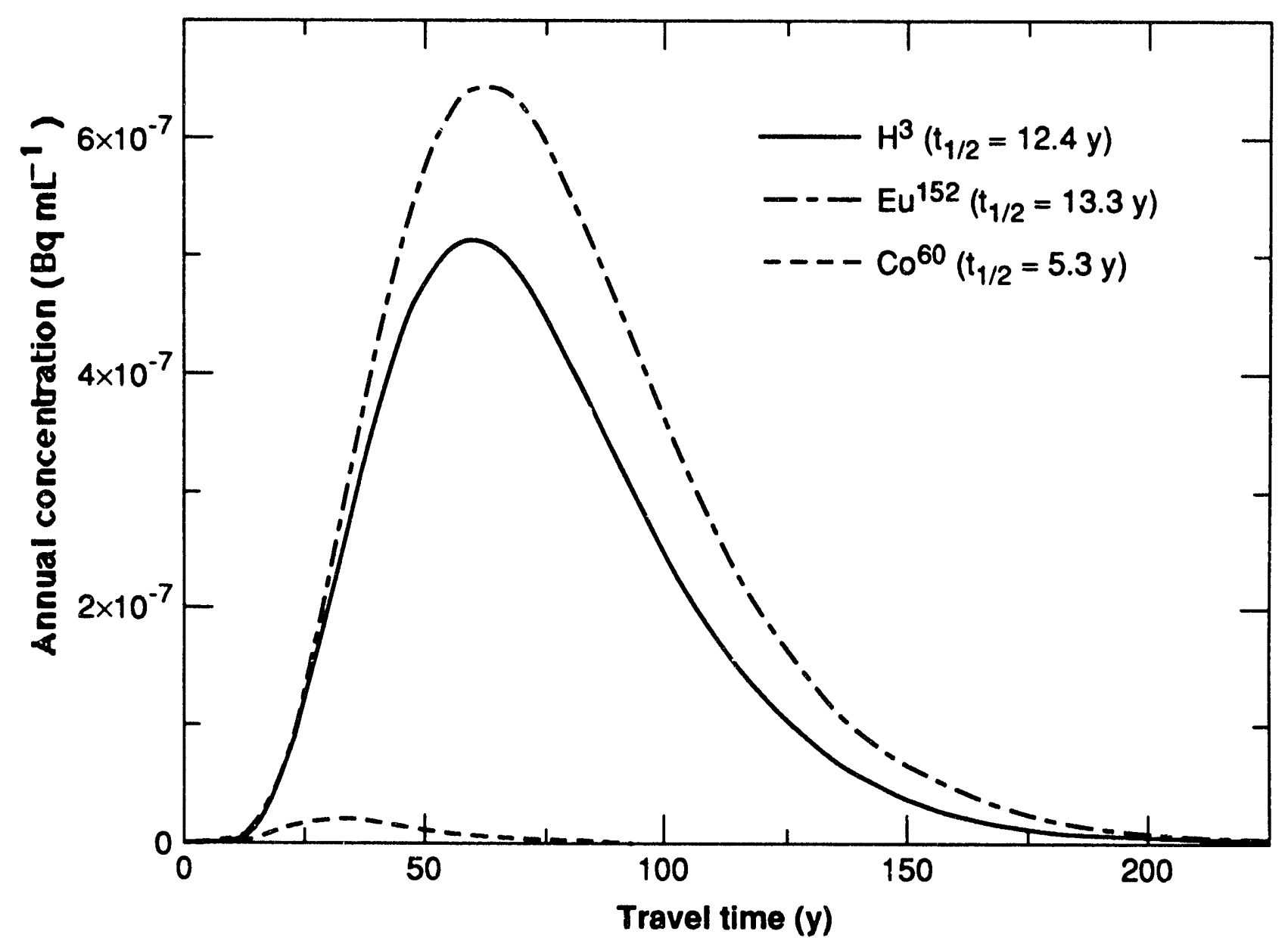

Figure 4. The impact of radioactive decay on travel-time probablity-denslty function (pdi) for three different radionuclides.

stated previously, retention of individual radionuclides on geologic material along the flow path to the Oasis Valley was not taken into consideration. For simplicity, all three radionuclides used in this illustration are considered to be at the same initial concentration in ground water at the Area 20 boundary. Comparison of the curves in Figure 4 reveals that the shorter the radioactive half-life, the more the peak of the pdf flattens (i.e., the maximum values of the maximum annual concentrations are reduced) and shifts toward the origin, with a smaller total quantity of radioactive material arriving at the Oasis Valley, annually and cumulatively. Accordingly, it is only because there is an infinitesimally small probability of relatively fast groundwater flow, such as might occur through fractures, caves, or along faults (as manifested in a tail of the lognormal model of the velocity distribution), that any radionuclide with a short radioactive halflife would be predicted to arrive at the Oasis Valley. 


\section{Intake of Radionuclide-Contaminated Ground Water}

The first scenario to be examined concerns an individual living on the NTS in the immediate vicinity of the Area 20 boundary, some 101 years from now, when institutional control of the NTS is assumed to have been lost. Although access to the deep ground water at this location is considered feasible, acquisition of this ground water would be difficult and expensive because of its depth. Nonetheless, for purposes of this assessment, it is assumed that the deep ground water at this location will be accessible, this water will represent the only source of drinking water, an individual will consume exclusively' this water and its radionuclide constituents, and that such exposure will begin at birth and continue without interruption over an entire 70-y lifespan.

The second scenario focuses on an individual living in the immediate vicinity of the springs at Oasis Valley, presumably as a consequence of northward expansion of the nearby community of Beatty (see Figs. 1 and 3). Again, this offsite vicinity is of interest because it represents the nearest practical location to any boundary of the NTS where potential human exposure to ground water migrating from the NTS could occur. The ground water in this offsite vicinity is much shallower and will be more accessible as a source of drinking water, both technically and financially, than on the NTS itself.

Because the travel-time transport model indicates that the 70-y interval of maximum annual concentrations will be different for many of the radionuclides arriving at the Oasis Valley from the Area 20 boundary (see last column of Table 2), it is highly unlikely that an individual could be exposed to ground water containing all of the radionuclides together at their 70 predicted maximum annual concentrations (ranges also shown in Table 2). Nevertheless, estimates of dose and health risk are derived. This approach is taken to ascertain whether one radionuclide could dominate the dose more than any of the others, and whether the estimate of risk is of sufficient concern to indicate that a more realistic, but far more complicated, analysis of risk is warranted. Again, it is assumed that the ground water in the Oasis Valley will be accessible, will represent the only source of drinking water, will be consumed exclusively, and that such exposure will begin at birth and continue without interruption over an entire 70-y lifespan.

Data compiled by Ershow and Cantor (1989) from a U.S. survey of tapwater intake shows that the rate of intake increases with age, and can vary by geographic region (presumably as a consequence of climate) for both sexes and all seasons of the year. In that survey, tap water was assumed to be from a local source and was defined as water consumed either directly for drinking, or indirectly, in preparation of foods or other beverages, such as tea and coffee. Of primary interest was tapwater intake from birth to age 70 for an individual living in the southern part of Nevada. Therefore, dose estimations for someone living on or near the NTS are based on age-specific tapwater intake for both sexes and broad age categories for the western region of the U.S., quantified by Ershow and Cantor (1989).

The rate of tapwater intake is assumed to be a lognormally distributed variable. Shown in Table 3 are the weighted arithmetic mean $\left(\bar{x}_{e}\right)$ and standard deviation $\left(s_{e}\right)$ values for age-specific annual tapwater intake for the western United States reported by Ershow and Cantor (1989). Table 3 also contains the corresponding geometric mean $\left(\mathrm{GM}_{\mathrm{e}}\right)$ and geometric standard deviation 
Table 3. Summary of annual tapwater intake $\left(\mathrm{L}^{-1}\right)$ for both sexes by broad age category and over all seasons for the western United States, including Nevada (from Ershow and Cantor, 1989) $)^{b}$.

\begin{tabular}{|c|c|c|c|c|}
\hline \multirow[b]{2}{*}{$\begin{array}{l}\text { Age } \\
\text { (y) }\end{array}$} & \multicolumn{2}{|c|}{ Weighted arithmetic } & \multicolumn{2}{|c|}{ Corresponding geometric } \\
\hline & Mean $\left(\bar{x}_{\ell}\right)$ & $\begin{array}{c}\text { Standard deviation } \\
\left(s_{e}\right)\end{array}$ & Mean $\left(G_{M_{e}}\right)$ & $\begin{array}{l}\text { Standard deviation } \\
\text { (GSD) }\end{array}$ \\
\hline 0 to1 & $1.3 \times 10^{2}$ & $1.0 \times 10^{2}$ & $1.0 \times 10^{2}$ & 1.97 \\
\hline 1 to 1 & $2.8 \times 10^{2}$ & $1.5 \times 10^{2}$ & $2.5 \times 10^{2}$ & 1.65 \\
\hline 11 to 20 & $3.6 \times 10^{2}$ & $21 \times 10^{2}$ & $3.1 \times 10^{2}$ & 1.72 \\
\hline 20 to 65 & $5.3 \times 10^{2}$ & $3.0 \times 10^{2}$ & $4.6 \times 10^{2}$ & 1.69 \\
\hline 65 to 70 & $5.6 \times 10^{2}$ & $2.3 \times 10^{2}$ & $5.2 \times 10^{2}$ & 1.48 \\
\hline
\end{tabular}

a Rounded values.

b Weighted arithmetic mean and standard deviation are reported in $\mathrm{mL} \mathrm{d}^{-1}$ by

Ershow and Cantor (1989), and converted to $\mathrm{L} \mathrm{y}^{-1}$ by multiplying by $365 \mathrm{~d} \mathrm{y}^{-1}$ and dividing by $10^{3} \mathrm{~mL} \mathrm{~L}^{-1}$.

$\left(G S D_{e}\right)$ values based on these reported age- and region-specific annual rates of tapwater intake. Because the logarithm of tapwater intake is assumed to be a normally distributed variable (i.e., tapwater intake is lognormally distributed), the respective $\mathrm{GM}_{e}$ and $\mathrm{GSD}_{\mathbf{e}}$ terms in Table 3 are derived using the following expressions (from $\mathrm{Ng}$ et al., 1990):

$$
\begin{aligned}
& \mathrm{GM}_{\mathrm{e}}=\frac{\overline{\mathrm{x}}_{\mathrm{e}}^{2}}{\sqrt{\overline{\mathrm{x}}_{\mathrm{e}}^{2}+\mathrm{s}_{\mathrm{e}}^{2}}} \text {, and } \\
& \mathrm{GSD}_{\mathrm{c}}=\exp \sqrt{\ln \left[1+\left(\frac{\mathrm{s}_{e}^{2}}{\bar{x}_{e}^{2}}\right)\right]} .
\end{aligned}
$$

\section{Dose Corresponding To Intake}

Before the potential excess-cancer risk for an individual consuming radionuclidecontaminated ground water can be quantified, it is first necessary to estimate the internal radiation dose corresponding to these exposures. Because ingestion of the contaminated ground water represents the primary exposure pathway, other potential pathways $(e . g .$, inhalation and dermal absorption associated with bathing, and ingestion of contaminated locally grown fruits and vegetables) will not be considered to contribute substantially to the internal dose.

The approach for constructing an individual's lifetime estimate of internal radiation dose is based on the dosimetric formalisms adopted for this purpose by the International Commission on Radiological Protection (ICRP) and described in ICRP Publication 60 (ICRP, 1991a). The ICRP methodology was developed for the purpose of radiation protection and readily addresses a substantial number of radionuclides. By design, it provides an estimate of the total dose an 
individual is committed to receive from an internally deposited radionuclide, which equates not only to the dose delivered during the year of intake but also to any dose delivered in the future as a result of the continued presence of the radionuclide in the body (NCRP, 1987). However, for those radionuclides that are retained in the body for only a short amount of time or have short radioactive half lives (i.e., equating to effective half lives of less than or equal to about three months), the committed total dose from a single intake will numerically approximate the annual dose from a continuous intake for one year. Thus, the committed total dose determined by this process will overestimate only the committed annual dose from the intake of those radionuclides that have both long radioactive half lives and long physiological retention times (i.e., lengthy effective half lives). Because radionuclides of both types are considered to be in the NTS ground water, only some of these radionuclides will contribute to any overestimate of the total ingested dose. Revising the ICRP methodology to reduce such error is unnecessary, as this procedure is being used here primarily to screen for those radionuclides making the greatest contribution to potential excess lifetime dose and risk and to indicate the possible magnitude of such risk. Additionally, such error will be small should a radionuclide with a short effective half-life (e.g., tritium) be shown to dominate the dose.

The procedure for calculating an individual's dose from the intake of a specific radionuclide over a 70-y lifetime involves summing over that exposure period the products of (1) the appropriate age-specific dose-conversion factor for each year of a $70-\mathrm{y}$ lifespan $\left(\mathrm{Sv} \mathrm{Bq}{ }^{-1}\right)$, (2) the corresponding age-related annual intake of tap water $\left(\mathrm{L} \mathrm{y}^{-1}\right)$, and (3) the annual estimate of the concentrations of the radionuclide in the water $\left(\mathrm{Bq} \mathrm{L}^{-1}\right)$ at a specific location. The latter two factors have already been described. In the sections that follow, the age-specific dose-conversion factors are derived. Then the derivation and estimation of the maximum 70-y lifetime dose, including the associated uncertainties, are presented for an individual exposed to the maximum annual radionuclide concentrations in ground water at either the Area 20 boundary or offsite at Oasis Valley.

\subsection{Dose-Conversion Factors for Intake by Ingestion}

Age-dependent, organ-specific, committed equivalent doses per unit of radioactive material ingested $\left(\mathrm{Sv} \mathrm{Bq}{ }^{-1}\right)$ for the most radiologically significant radionuclides released into the environment were compiled for the general public in ICRP Publication 56 (ICRP, 1990). These committed equivalent doses were calculated by the ICRP using biokinetic data and dosimetric models. In this process, the absorbed dose averaged over a specific target tissue or organ $\left(\mathrm{Gy} \mathrm{Bq}^{-1}\right)$ is weighted by a factor that relates the type and energy emitted by the radionuclide to the effectiveness of that radiation, compared to other radiations, for inducing stochastic effects. This term is the radiation weighting factor. Also addressed in these calculations is the effect of age on both the biokinetics of a radionuclide and on human physiological and anatomical properties. Additionally, the committed equivalent doses for radionuclides tabulated in ICRP Publication 56 represent total equivalent doses accumulated by tissues or organs as a consequence of varying dose rate and protraction of exposure over a time period following intake. This time period is considered to be $70 \mathrm{y}$ for infants, children, and adolescents, and $50 \mathrm{y}$ for adults.

The concept of committed effective dose (ICRP, 1991a) allows doses resulting from tissue or organ (partial-body) exposures, which can result from ingestion of radionuclides, to be converted 
into a dose to the whole body that has an equal level of risk associated with it (Moeller, 1992). In this approach, age-dependent committed effective doses are derived from age-dependent, organ-specific committed equivalent doses using tissue-weighting factors. Specifically, age-dependent committed effective doses per unit intake of activity $\left(\mathrm{Sv} \mathrm{Bq}^{-1}\right)$ are calculated by summing the products of organ-specific, committed equivalent doses for an age category and the tissue-weighting factors assigned to each of the specified tissues and organs of the body. As discussed by Moeller (1992), tissue-weighting factors represent the contributions to the total risk associated with exposures to specific tissues and organs, and they are determined by taking into consideration parameters that include the likelihood that radiation can induce a given cancer or genetic effect, and that account for years of life lost for those who die of latent cancers. Tissue weighting factors were revised in ICRP Publication 60 (ICRP, 1991a) to be consistent with the most current understanding of radiobiology, and thus the committed effective dose factors presented in ICRP Publication 56 (ICRP 1990) are no longer current.

Only 8 of the 16 radionuclides that are considered representative of the mix of radionuclides that are present today at the Area 20 boundary and that were measured in ground water collected from the three specific shot cavities (see Table 1) have age-dependent, organ-specific committed equivalent doses tabulated in ICRP Publication 56 (ICRP, 1990). To calculate age-dependent committed effective doses for these eight radionuclides-(1) Americium-241 (Am-241), (2) Cerium-144 (Ce-144), (3) Cesium-137, (4) Iodine-129 (I-129), (5) Plutonium-239 (Pu-239), (6) Ruthenium-106, (7) Strontium-90, and (8) Tritium (H-3)-each organ-specific committed equivalent dose in a given age category for each radionuclide was multiplied by its respective tissue-weighting factor and the products for that age category were then summed. The resulting age-category-dependent committed effective doses agree with those calculated for these radionuclides and age-categories by Jain et al. (1992) using an analogous procedure. For purposes of this report, these age-category specific committed effective doses $\left(\mathrm{Sv} \mathrm{Bq}^{-1}\right)$ were considered to apply to each year of life identified for that age category by the ICRP (1990) in ICRP Publication 56. Consequently, these annual age-specific committed effective doses are the dose-conversion factors used for estimating the lifetime dose for each of these eight radionuclides in NTS ground water.

Similar dose-conversion factors were calculated for each of the remaining eight radionuclides of interest (see Table 1)-(9) Antimony-125 (Sb-125), (10) Cobalt-60(Co-60), (11) Europium-152 (Eu-152), (12) Radium-226 (Ra-226), (13) Technetium-99 (Tc-99), (14) Uranium-234 (U-234), (15) Uranium-235 (U-235), and (16) Uranium-238 (U-238)-using the recommended annual limit on intake (ALI) for occupational exposures resulting from ingestion of these radionuclides. These ALIs are published in ICRP Publication 61 (ICRP, 1991b). The ALI (Bq) for any radionuclide for occupational exposure through ingestion is derived by dividing the recommended annual average effective dose limit for occupational exposure $(0.02 \mathrm{~Sv})$ by the committed effective dose per unit of radioactive material ingested $\left(\mathrm{Sv} \mathrm{Bq}{ }^{-1}\right.$ ) for the 50-y period following intake by an adult. Thus, even though the ICRP has not yet explicitly provided revised values of committed effective doses per unit of activity for these eight radionuclides, the committed effective dose per unit of radionuclide intake for a 50-y period following intake during any year of life in the adult-age category can still be determined. For the public, however, adjustments must be made in these age-dependent committed effective doses (i.e., increasing the dose commitment from 50 to $70 \mathrm{y}$ ). The result of this adjustment is the annual age-specific committed effective dose for a $70-y$ period following intake of each 
radionuclide. This quantity is considered to be the dose-conversion factor applicable to all ages beginning at birth and lasting over an entire 70-y lifespan.

For those radionuclides having a relatively long biological half-life (i.e., retained in tissues or organs), compared to a 70-y lifetime of chronic ingestion exposure, protracted internal exposure can occur. The adjustment factor with the least amount of error for converting the committed effective dose for adult ages to one applicable to all ages for these radionuclides equates to the ratio of a radionuclide-specific retention function, integrated over $70 \mathrm{y}$, to the same retention function integrated over $50 \mathrm{y}$. The radionuclides in this category are Ra-226, U-234, U-235, and $\mathrm{U}-238$. The adjustment factor for Ra-226 is 1.2 and was estimated from the integrals of the retention function for the whole body for infinite time after exposuse (which was used as a surrogate for $70 \mathrm{y}$ after exposure) and for $50 \mathrm{y}$ after exposure. These integrals of the retention function for the whole body for Ra-226 are presented in Table 36 of ICRP Publication 20 (ICRP, 1973). The adjustment factor for all three isotopes of uranium $(234,235$, and 238$)$ is 1.1 , and was obtained from the ratio of the retention function for bone integrated over $70 \mathrm{y}$ and over $50 \mathrm{y}$. The retention function for bone for uranium is presented in ICRP Publication 30, Part 1 (ICRP, 1979).

For radionuclides with biological half lives that are relatively negligible compared to a $70-y$ lifetime, the adjustment factor is obtained by dividing 70 y by 50 y (i.e., 1.4). The radionuclides for which this adjustment factor was used are Sb-125, Co-60, Eu-152, and Tc-99.

Table 4 summarizes the radionuclide-specific, age-dependent dose-conversion factors calculated for all 16 radionuclides of interest. Each value is assumed to represent the geometric mean (GM) of a lognormally distributed variable. The geometric standard deviation (GSD) associated with each GM in Table 4 is assumed to be equal to 1.8. This assumption is based on the one made by $\mathrm{Ng}$ et al. (1990) in which a default geometric standard deviation of 1.8 is assumed for ingestion dose factors for all target organs for which a GSD is not specified.

\subsection{Maximum Dose and Associated Uncertainty}

As previously indicated, it is assumed that the estimates of the (i) annual concentrations $\left(\mathrm{Bq} \mathrm{L}^{-1}\right)$ for the radionuclide; of interest in ground water at a particular location, (2) agedependent annual rates of tapwacer intake $\left(\mathrm{L} \mathrm{y}^{-1}\right)$ for individuals in Nevada, and (3) agedependent dose-conversion factors $\left(\mathrm{Sv} \mathrm{Bq}^{-1}\right)$ for the radionuclides of interest, are all lognormally distributed variables. Lognormality was assumed for these variables because in all three instances, two conditions commonly used as criteria for making this assumption are satisfied: the values are constrained to be positive, and the variability for each quantity is considered relatively large with respect to the mean (Puskin, 1992). As a result of making this assumption, the mathematical procedures described by Hoffman and Gardner (1983) and by $\mathrm{Ng}$ et al. (1990) can be applied to estimate the statistical parameters and their uncertainty for the distribution resulting from the combination of these lognormally distributed variables.

Table 5 contains the arithmetic means and variances for the lifetime committed effective doses received by an individual from ingestion of the respective radionuclides in ground water during their respective 70-y intervals of maximum annual concentrations (or intakes) at either the 
Table 4. Summary of estimated radionuclide-specific, age-dependent (committed effective) dose-conversion factors ( $\mathrm{Sv} \mathrm{Bq}{ }^{-1}$ ) for the 16 radionuclides of interest; all values are assumed to be geometric means and to have geometric standard deviations equal to 1.8 .

\begin{tabular}{|c|c|c|c|c|c|c|}
\hline \multirow[b]{2}{*}{ Radionucliale } & \multicolumn{6}{|c|}{ Chronological age category (applicable time period) } \\
\hline & $\begin{array}{c}3 \text { mo } \\
\text { (1 year) }\end{array}$ & $\begin{array}{c}1 y \\
\text { (1 year) }\end{array}$ & $\begin{array}{c}5 y \\
(5 \text { years) }\end{array}$ & $\begin{array}{c}10 y \\
\text { (5 years) }\end{array}$ & $\begin{array}{c}15 \mathrm{y} \\
\text { (5 years) }\end{array}$ & $\begin{array}{c}\text { Adult } \\
\text { (53 years) }\end{array}$ \\
\hline$A m-241^{a}$ & $7.3 \times 10^{-6}$ & $7.3 \times 10^{-7}$ & $5.7 \times 10^{-7}$ & $4.8 \times 10^{-7}$ & $4.7 \times 10^{-7}$ & $4.5 \times 10^{-7}$ \\
\hline$S b-125^{b}$ & $1.4 \times 10^{-9}$ & $1.4 \times 10^{-9}$ & $1.4 \times 10^{-9}$ & $1.4 \times 10^{-9}$ & $1.4 \times 10^{-9}$ & $1.4 \times 10^{-9}$ \\
\hline Ce-144ª & $1.1 \times 10^{-7}$ & $6.2 \times 10^{-8}$ & $3.0 \times 10^{-8}$ & $1.9 \times 10^{-8}$ & $1.0 \times 10^{-8}$ & $8.4 \times 10^{-9}$ \\
\hline Cs-137a & $2.0 \times 10^{-8}$ & $1.1 \times 10^{-8}$ & $8.9 \times 10^{-9}$ & $9.7 \times 10^{-9}$ & $1.3 \times 10^{-8}$ & $1.3 \times 10^{-8}$ \\
\hline $\mathrm{Co}-60^{\mathrm{b}}$ & $4.0 \times 10^{-9}$ & $4.0 \times 10^{-9}$ & $4.0 \times 10^{-9}$ & $4.0 \times 10^{-9}$ & $4.0 \times 10^{-9}$ & $4.0 \times 10^{-9}$ \\
\hline$E u-152^{b}$ & $2.8 \times 10^{-9}$ & $2.8 \times 10^{-9}$ & $2.8 \times 10^{-9}$ & $2.8 \times 10^{-9}$ & $2.8 \times 10^{-9}$ & $2.8 \times 10^{-9}$ \\
\hline$I-129^{a}$ & $1.9 \times 10^{-7}$ & $2.2 \times 10^{-7}$ & $1.7 \times 10^{-7}$ & $1.9 \times 10^{-7}$ & $1.4 \times 10^{-7}$ & $1.1 \times 10^{-7}$ \\
\hline $\mathrm{Pu}-239^{2}$ & $9.0 \times 10^{-6}$ & $9.0 \times 10^{-7}$ & $7.2 \times 10^{-7}$ & $5.9 \times 10^{-7}$ & $5.6 \times 10^{-7}$ & $5.5 \times 10^{-7}$ \\
\hline$R a-226^{b}$ & $2.8 \times 10^{-7}$ & $2.8 \times 10^{-7}$ & $2.8 \times 10^{-7}$ & $2.8 \times 10^{-7}$ & $2.8 \times 10^{-7}$ & $2.8 \times 10^{-7}$ \\
\hline Ru-106a & $1.2 \times 10^{-7}$ & $7.3 \times 10^{-8}$ & $3.7 \times 10^{-8}$ & $2.1 \times 10^{-8}$ & $1.3 \times 10^{-8}$ & $1.0 \times 10^{-8}$ \\
\hline Sr-90 & $1.2 \times 10^{-7}$ & $8.1 \times 10^{-8}$ & $3.6 \times 10^{-8}$ & $3.4 \times 10^{-8}$ & $4.5 \times 10^{-8}$ & $2.9 \times 10^{-8}$ \\
\hline Tc-99b & $9.3 \times 10^{-10}$ & $9.3 \times 10^{-10}$ & $9.3 \times 10^{-10}$ & $9.3 \times 10^{-10}$ & $9.3 \times 10^{-10}$ & $9.3 \times 10^{-10}$ \\
\hline $\mathrm{H}-3^{\mathrm{a}}$ & $5.5 \times 10^{-11}$ & $4.1 \times 10^{-11}$ & $2.6 \times 10^{-11}$ & $1.9 \times 10^{-11}$ & $1.6 \times 10^{-11}$ & $1.6 \times 10^{-11}$ \\
\hline$U-234^{b}$ & $3.0 \times 10^{-8}$ & $3.0 \times 10^{-8}$ & $3.0 \times 10^{-8}$ & $3.0 \times 10^{-8}$ & $3.0 \times 10^{-8}$ & $3.0 \times 10^{-8}$ \\
\hline$U-235^{b}$ & $3.0 \times 10^{-8}$ & $3.0 \times 10^{-8}$ & $3.0 \times 10^{-8}$ & $3.0 \times 10^{-8}$ & $3.0 \times 10^{-8}$ & $3.0 \times 10^{-8}$ \\
\hline U-238b & $2.6 \times 10^{-8}$ & $2.6 \times 10^{-8}$ & $2.6 \times 10^{-8}$ & $2.6 \times 10^{-8}$ & $2.6 \times 10^{-8}$ & $2.6 \times 10^{-8}$ \\
\hline
\end{tabular}

a Derived according to the method described in the text from age-dependent, ongan-apecific commilted equivalent doses appearing in ICRP Publication 56 (ICRP, 1990). Results agree with those computed by Jain et al. (1992) using a similar procedure.

b Derived according to the method described in the text from the annual limit on intake (ALI) for ingestion as given in ICRP Publication 61 (ICRP, 1991b).

boundary of Area 20 or at the Oasis Valley. According to these figures, at each location, tritium (H-3) is calculated to be responsible for nearly $90 \%$ of the total lifetime committed effective dose. These estimates were derived using the following procedures.

First, the geometric mean of an annual committed effective dose $\left(\mathrm{GM}_{\mathrm{CED}}\right)$ was calculated for a particular radionuclide by multiplying together the geometric mean values for each of the three factors identified above. Next, the total log-transformed variance for this annual dose was computed, and any correlation was accounted for between dose-conversion factor and annual intake. 
Table 5. Lifetime maximum 70-y committed effective doses (Sv) for radionuclides of interest at Area 20 and offsite, $19 \mathrm{~km}$ away at the Oasis Valley.

\begin{tabular}{|c|c|c|c|c|}
\hline \multirow[b]{4}{*}{ Radionuclide } & \multicolumn{4}{|c|}{ Lifetime committed effective dose (Sv) } \\
\hline & \multicolumn{2}{|c|}{ Area 20 boundary } & \multicolumn{2}{|c|}{ Qasis Valley } \\
\hline & \multicolumn{2}{|c|}{ Arithmetic } & \multicolumn{2}{|c|}{ Arithmetic } \\
\hline & mean & variance & mean & variance \\
\hline Americium-241 & $1.2 \times 10^{-3}$ & $5.4 \times 10^{-7}$ & $5.6 \times 10^{-7}$ & $3.3 \times 10^{-13}$ \\
\hline Antimony-125 & $1.6 \times 10-14$ & $1.7 \times 10^{-28}$ & $6.4 \times 10^{-12}$ & $6.6 \times 10^{-23}$ \\
\hline Cerium-144 & $4.4 \times 10^{-43}$ & $4.4 \times 10^{-86}$ & $4.6 \times 10^{-17}$ & $1.6 \times 10^{-33}$ \\
\hline Cesium-137 & $4.5 \times 10^{-3}$ & $2.1 \times 10^{-5}$ & $7.8 \times 10^{-7}$ & $1.3 \times 10^{-12}$ \\
\hline Cobalt -60 & $3.0 \times 10^{-12}$ & $6.1 \times 10^{-24}$ & $2.7 \times 10^{-13}$ & $1.2 \times 10^{-25}$ \\
\hline Europium-152 & $5.3 \times 10^{-8}$ & $2.0 \times 10^{-15}$ & $3.0 \times 10^{-11}$ & $1.4 \times 10^{-21}$ \\
\hline Iodine-129 & $1.5 \times 10^{-3}$ & $1.4 \times 10^{-7}$ & $1.1 \times 10^{-6}$ & $7.3 \times 10^{-13}$ \\
\hline Plutonium-239 & $4.8 \times 10^{-3}$ & $7.8 \times 10^{-6}$ & $3.6 \times 10^{-6}$ & $1.3 \times 10^{-11}$ \\
\hline Radium-226 & $1.1 \times 10^{-3}$ & $8.6 \times 10^{-7}$ & $7.2 \times 10^{-7}$ & $8.2 \times 10^{-13}$ \\
\hline Ruthenium-106 & $7.7 \times 10^{-33}$ & $1.2 \times 10^{-65}$ & $9.3 \times 10^{-14}$ & $6.7 \times 10^{-27}$ \\
\hline Strontium-90 & $6.5 \times 10^{-3}$ & $8.8 \times 10^{-6}$ & $1.1 \times 10^{-6}$ & $9.2 \times 10^{-13}$ \\
\hline Technetium-99 & $9.4 \times 10^{-5}$ & $6.0 \times 10^{-9}$ & $7.1 \times 10^{-8}$ & $8.1 \times 10^{-15}$ \\
\hline Tritium [H-3] & $1.4 \times 10^{-1}$ & $3.4 \times 10^{-3}$ & $7.7 \times 10^{-5}$ & $4.7 \times 10^{-9}$ \\
\hline Uranium-234 & $2.2 \times 10^{-4}$ & $3.2 \times 10^{-8}$ & $1.6 \times 10^{-7}$ & $4.3 \times 10^{-14}$ \\
\hline Uranium-235 & $3.8 \times 10^{-5}$ & $9.5 \times 10^{-10}$ & $2.8 \times 10^{-10}$ & $1.3 \times 10^{-19}$ \\
\hline Uranium-238 & $1.0 \times 10^{-3}$ & $7.1 \times 10^{-7}$ & $7.8 \times 10^{-7}$ & $9.6 \times 10^{-13}$ \\
\hline
\end{tabular}

The total log-transformed variance for an annual dose, where correlation between two terms is possible, was calculated using the following equation:

$$
\sigma_{1_{A}}^{2}=\sum_{i=a}^{c}\left(\ln G S D_{i}\right)^{2}+2 r\left(\ln G S D_{a}\right)\left(\ln G S D_{b}\right)
$$

where $\sigma_{l_{A}}^{2}$ is the total annual log-transform variance for the combined log-transformed variances and the variance attributable to correlated parameters; $\mathrm{GSD}_{\mathrm{i}}$ is the geometric standard deviation of the i-th variable (e.g., GSDs for annual dose-conversion factor, annual intake, and annual concentrations in ground water); $r$ is the linear correlation coefficient between two parameters (e.g., annual dose-conversion factor and annual rate of intake); and $\mathrm{GSD}_{\mathrm{a}}$ and $\mathrm{GSD}_{\mathrm{b}}$ are the geometric standard deviations of the correlated parameters. This equation and its application has been described by Hoffman and Gardner (1983) and by $\mathrm{Ng}$ et al. (1990).

Of course, it is not possible to examine the correlation between the dose-conversion factors and the intake for the eight radionuclides with dose-conversion factors derived from ALIs (i.e., Sb-125, Co-60, Eu-152, Ra-226, Tc-99, and U-234, U-235, and U-238). Consequently, the 
assumption was made that there is no correlation, and the correlation coefficient for these radionuclides has been set equal to zero. Because any real correlations would likely be negative, the net effect is to overestimate the variance.

For seven of the eight radionuclides that were calculated from ICRP Publication 56, the linear correlation coefficient was negative and was about -0.40 for both Am-241 and Pu-239; about -0.60 for Sr-90; about -0.70 for Ce-144, Ru-106, and H-3; and was highest for I-129, at a value of about -0.90 . The linear correlation coefficient was positive for Cs-137, at a value of about +0.40 , because the biological half-life of this radionuclide increases with age (Leggett, 1986).

The arithmetic niean of the annual committed effective dose, $\bar{x}_{\mathrm{CED}_{A}}$, was then determined using the following equation:

$$
\bar{x}_{\mathrm{CED}_{\mathrm{A}}}=\mathrm{GM}_{\mathrm{CED}_{\mathrm{A}}} \times \exp \left(\frac{1}{2} \sigma_{I_{\mathrm{A}}}^{2}\right),
$$

where $\mathrm{GM}_{C E D_{A}}$ is the geometric mean of the annual committed effective dose (Sv) and $\sigma_{l_{A}}^{2}$ is the total annual log-transform variance. The corresponding annual arithmetic variance, $s_{\mathrm{CED}_{A}}^{2}$, was calculated according to the following expression:

$$
\mathrm{s}_{\mathrm{CED}_{\mathrm{A}}}^{2}=\left(\mathrm{GM}_{\mathrm{CED}_{\mathrm{A}}}\right)^{2}\left[\exp \left(\sigma_{l_{\mathrm{A}}}^{2}\right) \times\left(\exp \left(\sigma_{1_{\mathrm{A}}}^{2}\right)-1\right)\right]
$$

The arithmetic mean and arithmetic variance of the annual committed effective dose for each year of a 70-y period of exposure was used to calculate the arithmetic mean and arithmetic variance of the lifetime committed effective dose. The arithmetic mean of the lifetime committed effective dose $\left(\bar{x}_{\mathrm{CED}_{1}}\right)$ for an individual radionuclide is simply the sum of the annual arithmetic means for that radionuclide. The arithmetic variance has two terms: the sum of the annual arithmetic variances and a co-variance term addressing the correlation between the presence of a radionuclide in the ground water in one year being positively correlated with its presence in the ground water during the next year. The linear correlation coefficient for this relationship is considered to be equal to 0.8 .

The total variance in the lifetime committed effective dose, $s_{\mathrm{T}_{\mathrm{L}}}^{2}$, is then the sum of the annual arithmetic variances and the sum of covariance terms that account for the correlations between years to the total dose:

$$
s_{\mathrm{T}_{L}}^{2}=\sum_{j=1}^{70} s_{j_{C E D_{A}}^{2}}^{2}+2 r_{k, l} \sum_{k=1}^{70-1} \sum_{l=k+1}^{70} s_{k_{C E D_{A}}} s_{l_{C E D_{A}}},
$$

where $s_{\mathrm{j}_{C E D}}^{2}$ is the annual arithmetic variance, $r_{k, 1}$ is the correlation coefficient describing the correlation in committed effective dose between years (i.e., assumed to be 0.8 ), and $\mathrm{s}_{\mathrm{k}_{\mathrm{CED}_{\mathrm{A}}}}$ and 
$\mathrm{s}_{\mathrm{CED}_{\mathrm{A}}}$ are the arithmetic standard deviations of annual variance for a radionuclide from year $\mathrm{k}$ and year 1 .

Because an estimate of the maximum potential risk confronting an individual ingesting NTS ground water either at the boundary of Area 20 or at the Oasis Valley is of primary interest, the maximum dose must first be calculated. At the Area 20 boundary on NTS, the maximum dose is that dose resulting from ingestion of all the radionuclides considered to be representative of those in the ground water during the 70-y interval beginning $101 \mathrm{y}$ in the future. At Oasis Valley, the maximum dose is that considered to result from ingesting the 70 maximum annual concentrations of each of the representative mix of radionuclides that have been modeled to be present at this location following transport in the ground water from the boundary of Area 20. Although the likelihood of all such radionuclides being present at the Oasis Valley simultaneously at their maximum concentration is very small, it is not impossible and, given the limited nature of the data concerning radionuclide concentrations in ground water beneath the NTS and their rate of movement, this assumption is not regarded as overly conservative.

The next item to be computed was the geometric mean and geometric standard deviation for the lognormally distributed committed effective dose associated with exposure to the maximum concentrations of all radionuclides of concern present simultaneously over a 70-y interval either at the Area 20 boundary or at the Oasis Valley. This was accomplished using the respective arithmetic means and arithmetic standard deviations for these radionuclides appearing in Table 5.

First, the arithmetic means of the lifetime committed effective doses associated with individual radionuclides at a specific location are summed to yield an arithmetic mean for the maximum potential lifetime committed effective dose from exposure to maximum concentrations from the grand total of all 16 radionuclides of concern, $\bar{x}_{\mathrm{CED}_{\mathrm{GTL}}}$. The associated arithmetic variance in the maximum possible committed effective dose over a 70-y lifetime has two terms: the sum of the arithmetic variances of the committed effective doses over a 70-y lifetime for each radionuclide and a co-variance term addressing the correlation between contributions of pairs of radionuclides to the total lifetime committed effective dose. Based on the linear correlation coefficients derived by $\mathrm{Ng}$ et al. (1990) for several radionuclides, the linear correlation coefficient for this relationship was assumed to be equal to 0.8 . The total variance in the lifetime committed effective dose from all radionuclides of concern, $s_{C E D}^{2}$, at a specific location was then calculated according to the following equation:

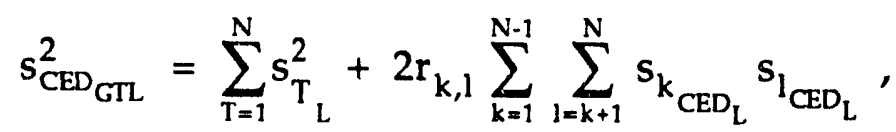

where $s_{T_{L}}^{2}$ is the total lifetime arithmetic variance for an individua'. radionuclide; $r_{k, 1}$ is the linear correlation coefficient between lifetime committed effective doses from radionuclides $\mathbf{k}$ and 1 (i.e., assumed to be 0.8); $\mathrm{s}_{\mathrm{KCED}_{\mathrm{L}}}$ and $\mathrm{s}_{\mathrm{CED}_{\mathrm{L}}}$ are the arithmetic standard deviations of the lifetime committed effective dose from radionuclides $\mathrm{k}$ and $\mathrm{l}$; and $\mathrm{N}$ equals 16.

The geometric mean of the lifetime committed effective dose from exposure to the grand total of all 16 radionuclides of concern $\left(\mathrm{GM}_{\mathrm{CED}} \mathrm{GTL}_{\mathrm{T}}\right)$ at a specific location is determined from the grand total arithmetic mean and arithmetic variance of the committed effective dose: 


$$
\mathrm{GM}_{\mathrm{CED}_{\mathrm{GTL}}}=\frac{\overline{\mathrm{x}}_{\mathrm{CED}_{\mathrm{GTL}}}^{2}}{\sqrt{\overline{\mathrm{x}}_{\mathrm{CED}_{\mathrm{CTL}}}^{2}+\mathrm{s}_{\mathrm{CED}_{\mathrm{CT}}}^{2}}} .
$$

The associated geometric standard deviation of the lifetime committed effective dose from exposure to all 16 radionuclides $\left(\mathrm{GSD}_{\mathrm{CED}_{\mathrm{GTL}}}\right)$ also is computed from the arithmetic mean and arithmetic variance of the committed effective dose for lifetime exposure to the grand total of all 16 radiounuclides:

$$
\operatorname{GSD}_{\mathrm{CED}_{\mathrm{GTL}}}=\exp \left(\sqrt{\ln \left(1+\frac{\mathrm{s}_{\mathrm{CED}_{\mathrm{GTL}}}^{2}}{\overline{\mathrm{x}}_{\mathrm{CED}}^{2}}\right)}\right) .
$$

For an individual exposed from birth for a 70-y lifetime at the Area 20 boundary, the $\mathrm{GM}_{\mathrm{CED}_{\mathrm{GTL}}}$ equals $1.5 \times 10^{-1} \mathrm{~Sv}$ and the corresponding GSD $\mathrm{CED}_{\mathrm{GTL}}$ equals 1.4. Similarly, for the individual exposed from birth for a 70-y lifetime at Oasis Valley, the $G_{C_{C E D}}$ GTL equals $6.5 \times 10^{-5} \mathrm{~Sv}$ and the corresponding GSD $\mathrm{CED}_{\mathrm{GTL}}$ equals 2.1. As a minor point, it should be noted that the Am-241 still will be growing in from the decay of its parent, $\mathrm{Pu}-241$. As the measured value of Am-241 was reported seven years after its associated event (the nuclear weapons test that served as its source), it is estimated that the final Am-241 concentration will be about three times higher. Even so, Am-241 would be less important than Sr-90, and Pu-239; and tritium would still dominate overwhelmingly the contribution to dose.

\section{Estimate of Cancer Risk and Associated Uncertainty}

The ICRP (1991a) in ICRP Publication 60, and the National Research Council (NRC) Committee on the Biological Effects of Ionizing Radiation (BEIR) in the BEIR V report (NRC, 1990) provide important reviews regarding the effectiveness of various forms of radiation to induce fatal cancers in humans and, specifically, the associated risks. The information in these reviews was directly applicable for identifying an appropriate estimate of the risk factor for radiation induced fatal cancer related to intake of radionuclides in ground water and for evaluating the uncertainty in this estimate.

On the basis of the data regarding excess mortality due to radiation induced cancers for human populations that are discussed in the BEIR V report (NRC., 1990), the risk factor for fatal cancer was considered to be a lognormally distributed variable. In ICRP Publication 60, the ICRP (1991a) averaged various estimates of the risk factor for radiation induced fatal cancers from different studies, including the BEIR V report (NRC, 1990), and arrived at a nominal risk value of $5 \times 10^{-2}$ per Sv of lifetime committed effective dose for the probability of induced fatal cancer in a population of all ages following chronic low-dose exposure. For purposes of this report, this risk factor is considered to be the geometric mean value $\left(G_{R F}\right)$ of a lognormally distributed variable. Also, the assumption is made that the population for which this risk factor is applicable remains stationary, has the age distribution of the current U.S. population, and a male to female ratio of unity - population characteristics that will not change over time. 
Discussions contained in the BEIR V report (NRC, 1990) and in ICRP Publication 60 (ICRP, 1991a) indicate that the total variability associated with the risk factor for fatal cancer from chronic low-dose exposure is attributed primarily to uncertainties contributed by (1) the chance sampling variation in the available epidemiological data from Japanese survivors of the 1945 atomic bomb explosions that are used for describing the relationship between increased cancer mortality and an elevated acute whole-body dose in predictive models; (2) the dose-rate effectiveness factor (DREF) that is used to adjust dose-response data for elevated acute wholebody dose to agree with evidence from animal studies and limited human data suggesting that cancer induction at low doses and low dose rates is likely to be lower than that observed after high dosts and dose rates; and (3) elements external to model parameters, including model misspecification with regard to males and females, population differences (e.g., Oriental vs. Occidental), uncertainiy in the actual dosimetry estimates, and the accuracy of the estimated doses to the people on whom these risk factors are based (most particularly, the Japanese survivors of the atomic bombs). In fact, a review of the estimated doses to the Japanese survivors currently is in progress and the results colld lead to future adjustments in the risk factor.

Each of these thiee components is assumed to be lognormally distributed and the associated geometric standard deviations are derived using the applicable data appearing in BEIR V (NRC, 19:10). For example, the geometric standard deviation for the first two components $\left(\mathrm{GSD}_{\mathrm{c}}\right)$ is obtainer by inserting the $95 \%$ upper confidence limit (UCL) and $5 \%$ lower confidence limit (LCL) describing the range of the $90 \%$ confidence interval for each component into the following equation:

$$
\mathrm{GSD}_{\mathrm{c}}=\left(\frac{95 \% \mathrm{UCL}}{5 \% \mathrm{LCL}}\right)^{\frac{1}{3.29}}
$$

The geometric tandard deviation of the third component was obtained by combining the GSDs for males and females for all cancers that were construcied from estimates of the GSDs for all nonmodel attributes contributing to the total variability in this component.

Because of sampling variation alone, the $90 \%$ confidence interval for risk of increased cancer mortality due to an acute whivle-body dose for males and iemales combined was reported to range from 0.11 per $S v$ to 0.24 Je: $S v$, yielding a $G_{S D}$ for this component of $i .3$. It is assumed that the narrow range from 2 to 5 reprrted for the DREF, as a result of a review of laboratory animal studies focusing on tumorigenesis, represents the limits for the $90 \%$ confidence interval, and the resultirg $\mathrm{GSD}_{\mathrm{c}}$ for this component also is 1.3 . Finally, the $\mathrm{GSD}_{\mathrm{c}}$ associated with overall uncertainty contributed by all of the elements considered external to model parameters was assumed to equal that calculated by adding in quadrature the natural logarithms of the male GSD of 1.31 and the female GSD of 1.27. The mathematical expression for deriving the GSD ${ }_{c}$ for this thirc component is

$$
\operatorname{GSD}_{\mathrm{c}}=\exp \sqrt{\left(\ln G S D_{\text {male }}\right)^{2}+\left(\ln G S D_{\text {female }}\right)^{2}},
$$


and it produces a value equal to 1.4. The geometric standard deviation of the total error for the risk factor (GSDTRF), which reflects the contribution to overall uncertainty from all three components, is derived using a formula similar to Eq. 16:

$$
\mathrm{GSD}_{\mathrm{TRF}}=\exp \sqrt{(\ln 1.3)^{2}+(\ln 1.3)^{2}+(\ln 1.4)^{2}}
$$

Accordingly, the GSD TRF equals 1.65 .

The geometric mean of the maximum potential excess lifetime risk of cancer mortality ( $\left(\mathrm{GM}_{\mathrm{MPR}}\right.$ ) for an individual either at Area 20 or at Oasis Valley from ingestion of the estimated maximum annual concentrations of the 16 radionuclides of interest in ground water at these locations was obtained as the product of the geometric mean of the total committed effective dose $\left(\mathrm{GM}_{\mathrm{CED}} \mathrm{GTL}\right)$ and the geometric mean of the risk factor $\left(\mathrm{GM}_{\mathrm{RF}}=0.05 \mathrm{~Sv}^{-1}\right)$. The total geometric standard deviation for this risk is determined by solving the following equation, which is analogous to Equation 16:

$$
\mathrm{GSD}_{\mathrm{MPR}}=\exp \sqrt{\left(\ln \mathrm{GSD}_{\mathrm{CED}_{\mathrm{GT}}}\right)^{2}+\left(\ln \mathrm{GSD}_{\mathrm{TRF}}\right)^{2}}
$$

For an individual at the Area 20 boundary, the GMMPR equals $7 \times 10^{-3}$ and the GSDMPR equals about 1.9. For an individual in the Oasis Valley, the $\mathrm{GM}_{M P R}$ equals $7 \times 10^{-7}$ and the

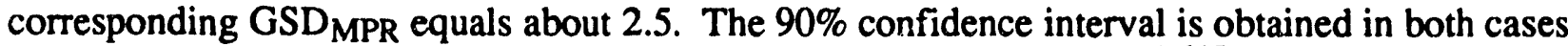
by multiplying the respective $G_{M} M_{M R}$ by the corresponding $G_{S D} S_{M P R} \pm 1.645$. The resulting range of risk for an individual in Oasis Valley is from $7 \times 10^{-7}$ to $1 \times 10^{-5}$, and for an individual at the Area 20 boundary the range of risk is from $3 \times 10^{-3}$ to $2 \times 10^{-2}$.

\section{Discussion}

Clearly, there is a scarcity of useful data available concerning the con'entrations of radionuclides in the ground water beneath the NTS today, and regarding the rates and directions of the flow of this ground water. Therefore, some conservative assumptions were adopted in order to assess responsibly the potential human health risks from the possible intake of such radionuclide-contaminated ground water by individuals in the future, either at a location onsite (assuming a loss of institutional control after $100 \mathrm{y}$ ) or at one offsite (as a result of transport in migrating groundwater). For example, none of the radionuclides of concern were considered to undergo adsorption and retention on geologic material. Also, any potential for dilution of the radionuclide-contaminated ground water by uncontaminated water was ignored. Yet, these conservative assumptions, and even the use of the concept of committed effective dose, do not appear to lead to gross overestimates of dose and risk, providing the approximations of maximum concentrations of radionuclides in ground water that are used are reasonable. The reason for this is that tritium, which moves as water and has a shor effective half-life (both physical and biological half-life are short), was found to be responsible for nearly $90 \%$ of the total Iifetime committed effective dose, when the representative mix of radionuclides are considered to be present together at their maximum annual concentrations at either the onsite or 
the offsite locations of interest. Consequently, adsorption and retention of any radionuclide other than tritium on geologic media will mean the reduction of that particular radionuclide's concentration in the ground water, and a corresponding reduction in the contribution to the total ingested dose from that radionuclide. Based on the ICRP methodology for calculating dose, this reduction will be more for a radionuclide having a lengthy effective half-life. Accordingly, the tritium contribution to the total dose will be even greater than $90 \%$. Under such circumstances, the corresponding contribution of tritium to the total risk will also increase. Additionally, the travel-time transport model actually indicates that the risk from tritium at the offsite location in the Oasis Valley is likely to be greatest for an individual exposed between 25 and $94 \mathrm{y}$ in the future (see Table 2) and so exposures to ground water and the corresponding dose and risk occurring at this location before or after this $70-y$ interval will be lower.

A !though only ingestion of radionuclide-contaminated ground water was considered, this pathway of exposure probably accounts for substantially more than $50 \%$ of the total dose of tritium. Accordingly, the predicted ranges for risk might be greater, but probably only by as much as a factor of two, if all other possible exposure pathways also are considered. This possible increase is not very meaningful, given the variability in the available data, and so rigorously addressing such additional pathways is unnecessary for purposes of this screening exercise.

\section{Conclusions}

The results from the risk-based screening analysis are based on conservative assumptions, and, where possible, defined estimates of uncertainty. These results indicate that tritium will likely be the radionuclide constituting the dominant contribution to dose and risk for humans exposed to ground water from the NTS.

Incorporating the maximum observed concentrations of a representative mix of radionuclides obtained from groundwater samples-of-opportunity into the travel-time transport model yields projected concentrations for these radionuclides offsite that do not appear to pose a serious concern for human exposure and risk. For example, the U.S. Environmental Protection Agencv (USEPA, 1990) has established a goal for excess risk from exposure to contaminants $i$. environmental media of $1 \times 10^{-6}$, but also acknowledges that an excess risk as large as $1 \times 10^{-4}$ may 'e acceptable. Clearly, the $90 \%$ confidence interval for excess cancer mortality risk at Oasis Valley, which is from $7 \times 10^{-7}$ to $1 \times 10^{-5}$, concurs with this guidance. However, should tritium be present beneath the NTS today at 10 or 100 times the concentration considered to be maximum (see Table 1), then predicted ranges for risk could also be 10 to 100 times higher, respectively, according to the approach that has been used. These concentrations may be unlikely, but would be of possible concern, especially for individuais offsite.

The results of the risk-based screening analysis that was performed using maximum observed concentrations of radionuclides in ground water samples-of-opportunity also strongly suggest that a contingency plan may need to be developed for continuing institutional control of the NTS, ard its subterranean mineral and water rights, beyond $100 \mathrm{y}$ in the future. This conclusion is evident as a direct consequence of the possibility that a $90 \%$ confidence interval for the maximum possible cancer mortality risk for an individual consuming NTS ground water for a $70-\mathrm{y}$ lifetime beginning $101 \mathrm{y}$ in the future was determined to range from $3 \times 10^{-3}$ to $2 \times 10^{-2}$, 
and neither end of this range of risk would be considered acceptable according to the USEPA (1990), or probably any other state or federal agency.

More definitive conclusions with regard to the possible risk from lifetime exposure to radionuclide contaminated tap water, both on the NTS and offsite, may be obtained given a better understanding of the relationship between the radionuclides produced by underground weapons tests (radiochemical source term) and their presence in ground water (hydrologic source term). For example, the maximum concentrations of the radionuclides used in our risk-based screening analysis, even for tritium, were all measured in ground water obtained as samples-of-opportunity. Althorgh the existence of higher radionuclide concentrations in NTS ground water than were assumed here remain speculative, such higher concentrations may be considered possible, at least until the data base is improved. Thus, a dedicated groundwater-sanipling strategy, in combination with a realistic estimate of the quantities of radioactive material introduced beneath the NTS can lead to refined estimates of risk and improved decision making, especially with respect to contingency plans for institutional control and the dedication of limited resources for groundwater cleanup. On the basis of the data available today, the risk-based screening analysis provides a reasonable indication that dedicating limited resources for the cleanup of radionuclide contaminated ground water beneath the NTS may not be necessary. However, planning well into the future for maintaining institutional control of the NTS and/or its subterranean minerals and ground water resources is probably prudent. 


\section{References}

Andricevic, R., J. I. Daniels, and R. L. Jacobson (1993), "Radionuclide Migration Using T..dvel Time Transport Approach and Its Application in Risk Analysis," Desert Research Institute, Water Resources Center, Las Vegas, NV (Draft; submitted for publication to J. Hydrol.).

Blankennagel, R. K., and J. E. Weir (1973), Geohydrology of the Eastern Part of Pahute Mesa, Nevada Test Site, Nye County, Nevada, U.S. Government Printing Office, Washington, DC, U.S. Geological Survey Professional Paper 712-B.

Buddemeier, R. W. (1988), Hydrology and Radionuclide Migration Program 1985-1986 Progress Report, Lawrence 'ivermore National Laboratory, Livermore, CA, UCRL-53779.

Buddemeier, R. W., and D. Isherwood (1985), Radionuclide Migration Project 1984 Progress Report, Lawrence Livermore National Laboratory, Livermore, CA, UCRL-53628.

Dagan, G. (1982), "Stochastic Modeling of Groundwater Flow by Unconditional and Conditional Probabilities, 2. The Solute Transport," Water Resour. Res. 18, 835-848.

Dagan, G. (1984), "Solute Transport in Heterogeneous Porous Formations," J. Fluid Mech. 145, 151-177.

Dagan, G. (1987), "Theory of Solute Transport by Groundwater,"Annu. Rev. Fluid Mech. 19, 183-215.

Dagan, G., and V. Nguyen (1989), "A Comparison of Travel Time and Concentration Approaches to Modeling Transport by Groundwater," J. Contam. Hydrol. 4, 79-91.

Erikson, S., and R. L. Jacobson (1990, Draft), Overview of Radionuclide Migration Investigations Conducted on the Nevada Test Site, Water Resources Center, Desert Research Institute, University of Nevada System, Reno and Las Vegas, NV, DRAFT Publication \#45071; DOE/NV/1038-30 [Concentration maxima at time of collection obtained from raw data recorded by the U.S. Environmental Protection Agency (EPA) as part of the 1973 or 1974 U.S. EPA Long-Term Hydrologic Monitoring Program (LTHM)].

Ershow, A. G., and K. P. Cantor (1989), Total Water and Tapwater Intake in the United States: Population-Based Estimates of Quantities and Sources, Federation of American Societies for Experimental Biology, Bethesda MD, National Cancer Institute Order \#263-MD-810264.

Fraser, S. L. (1982), Radiochemical Determination of Iodine-129 in Water Pumped from the Site of an Underground Nuclear Explosion, Los Alamos National Laboratory, Los Alamos, NM, LA-UR-82-2468.

Hoffman, D. C., R. Stone, and W. W. Dudley, Jr. (1977), Radioactivity in the Underground Environment of the Cambric Nuclear Explosion at the Nevada Test Site, Los Alamos National Laboratory, Los Alamos, NM, LA-6877-MS (Informal Report).

Hoffman, F. O., and R. H. Gardner (1983), "Evaluation of Uncertainties in Radiological Assessment Models," in Radiological Risk Assessment: A Textbook on Environmental Dose Analysis, J. E. Till and H. R. Meyer, Eds., U. S. Nuclear Regulatory Commission, Washington, DC, NUREG/CR-3332, ORNL-5968, pp. 11-1 to 11-55. 
International Commission on Radiological Protection (ICRP) (1973), ICRP Publication 20. Alkaline Earth Metabolism in Adult Man (Pergamon Press, New York, NY).

International Commission on Radiological Protection (ICRP) (1979), ICRP Publication 30 , Part 1. Limits for Intakes of Radionuclides by Workers (Pergamon Press, New York, NY), Volume 2 No. $3 / 4$.

International Commission on Radiological Protection (ICRP) (1990), ICRP Publication 56. AgeDependent Doses to Members of the Public from Intake of Radionuclides: Part 1 (Pergamon Press, New York, NY), Volume 20 No. 2.

International Commission on Radiological Protection (ICRP) (1991a), ICRP Publication 60. 1990 Recommendations of the International Commission on Radiological Protection (Pergamon Press, New York, NY), Volume 21 No. 1-3.

International Commission on Radiological Protection (ICRP) (1991b), ICRP Publication 61. Annual Limits on Intake of Radionuclides by Workers Based on the 1990 Recommendations (Pergamon Press, New York, NY), Volume 21 No. 4.

Jain, S. C., A. Nagaratnam, A. R. Reddy, M. M. Gupta, and S. C. Mehtall (1992), "Revised AgeDependent Doses to Members of the Public from Intake of Radionuclides Using the New Tissue Weighting Factors," Radiat. Prot. Dosim. 40, 111-115.

Kreft, A., and A. Zuber (1978), "On the Physical Meaning of the Dispersion Equation and Its Solution for Different Initial and Boundary Conditions," Chem. Eng. Sci. 33, 1471-1480.

Leggett, R. W. (1986), "Predicting the Retention of Cs in Individuals," Health Phys. 50, 747-759.

Marsh, K. V. (1992), "Appendix A. Tests Fired Near or Below the Water Table," in Hydrology and Radionuclide Migration Program 1987 Progress Report, Lawrence Livernore National Laboratory, Livermore, CA, UCRL-53779-89.

Moeller, D. W. (1992), "Chapter 10. Standards," in Environmental Health (Harvard University Press, Cambridge, MA), pp. 205-228.

National Council on Radiation Protection and Measurements (NCRF) (1987), Recommendations on Limits for Exposure to Ionizing Radiation, National Council on Radiation Protection and Measurements, Bethesda, MD, NCRP Report N². 91.

National Research Council (NRC) (1990), Health Effects of Exposure to Low Levels of Ionizing Radiation, BEIR V (National Academy Press, Washington, DC).

Ng, Y. C., Anspaugh, L. R., and R. T. Cederwall (1990), “ORERP Internal Dose Estimates for Individuals," Health Phys. 59, 693-713.

Puskin, J. S. (1992), "An Analysis of the Uncertainties in Estimates of Radon-Induced Lung Cancer," Risk Analysis 12, 277-285.

Shapiro, A. M., and V. Cvetkovic (1988), "Stochastic Analysis of Solute Arrival Time in Heterogeneous Porous Media," Water Resour. Res. 24, 1711-1718. 
Silva, R. J., R. Evans, J. H. Rego, and R. W. Buddemeier (1986), "Technetium Analyses in the Radionuclide Migration Project," in Nuclear Chemistry Division FY 86 Annual Report, R. J. Borg, Scientific Ed., Lawrence Livermore National Laboratory, Livermore, CA, UCAR-10062/86, p. 3-14.

Spencer, L. (1992), "Water: The West's Most Misallocated Resource," Forbes 149(9), 68-74.

Taylor, G. I. (1921), "Diffusion by Continuous Movements," Proc. London. Math. Soc. 2, 196-212.

United States Environmental Protection Agency (USEPA) (1990), "National Oil and Hazardous Substances Pollution Contingency Plan, Final Rule (40 CFR Part 300)," Fed. Regist. 55(46), 8666-8865.

Winograd, I. J., and W. Thordarson (1975), Hydrogeologic and Hydrochemical Framework, South-Central Great Basin, Nevada-California, with Special Reference to the Nevada Test Site, U.S. Government Printing Office, Washington, DC, U.S. Geological Survey Professional Paper 712-C.

Wruble, D. T., and E. M. McDowell, Eds. (1990), Nevada Test Site Annual Site Environmental Report-1989, Volume I, U.S. Department of Energy, Nevada Operations Office, Las Vegas, NV, DOE/NV/10630-11 Volume 1. 

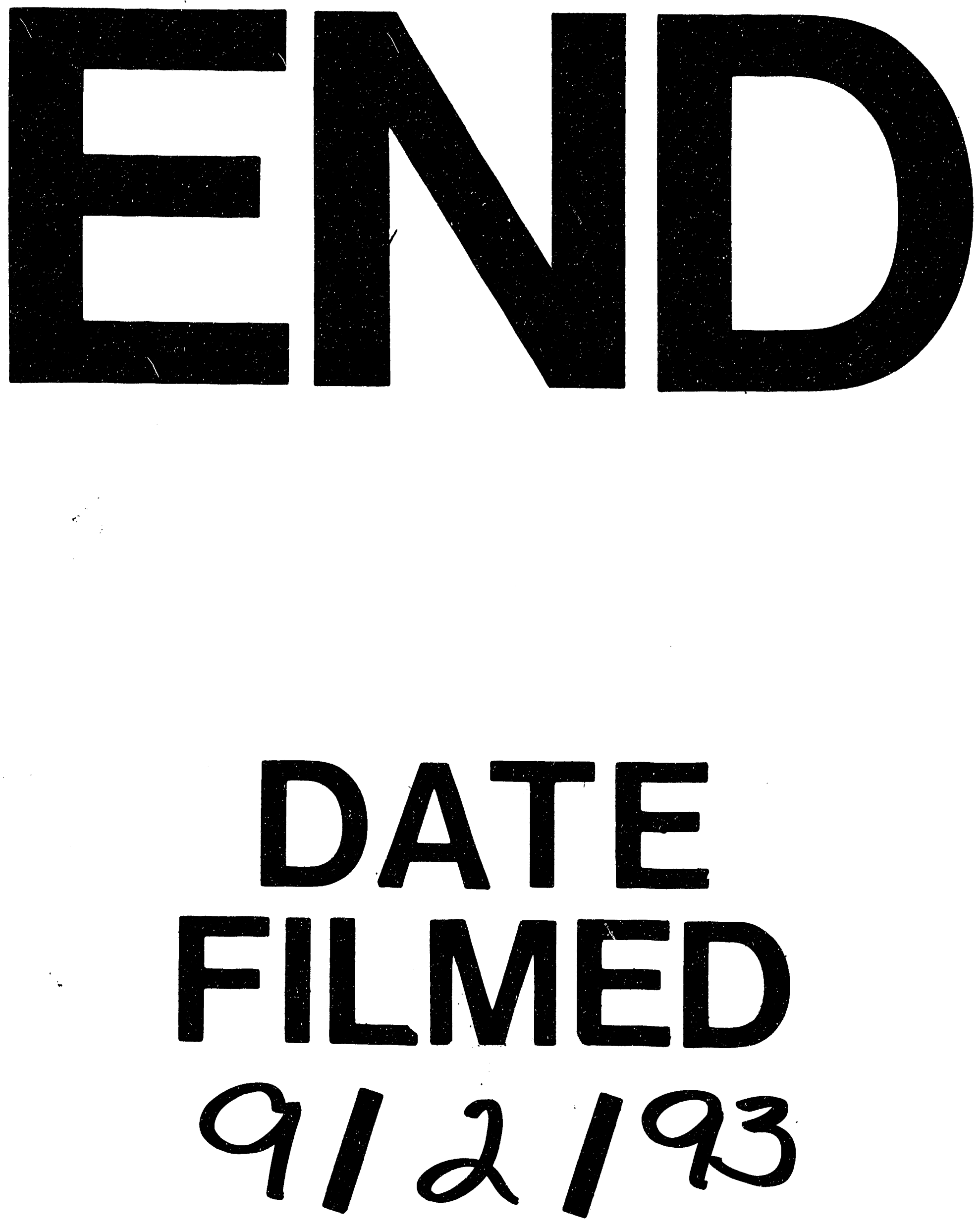
